University of Nebraska - Lincoln

DigitalCommons@University of Nebraska - Lincoln

\title{
"When I Can Read My Title Clear": Harriet Beecher Stowe and the Stowe v. Thomas Copyright Infringement Case
}

Melissa J. Homestead

University of Nebraska-Lincoln, mhomestead2@Unl.edu

Follow this and additional works at: https://digitalcommons.unl.edu/englishfacpubs

Part of the English Language and Literature Commons

Homestead, Melissa J., "'When I Can Read My Title Clear": Harriet Beecher Stowe and the Stowe v. Thomas Copyright Infringement Case" (2002). Faculty Publications -- Department of English. 45. https://digitalcommons.unl.edu/englishfacpubs/45 


\title{
"When I Can Read My Title Clear": Harriet Beecher Stowe and the Stowe v. Thomas Copyright Infringement Case \\ MELISSA J. HOMESTEAD
}

\begin{abstract}
$\mathbf{I}^{\mathrm{N}}$ N 1853, Harriet Beecher Stowe filed a copyright suit against F. W. Thomas, a Philadelphia printer who had published an unauthorized German translation of Uncle Tom's Cabin in his newspaper, Die Freie Presse. Stowe brought suit in the federal circuit court in Philadelphia, thus ironically placing her claim in the hands of Justice Robert Grier, a notable enforcer of slaver-owners' interests under the Fugitive Slave Law. Grier found that Stowe's property rights in her novelistic plea for resistance to the Fugitive Slave Law were very narrow and that she could not prevent Thomas from publishing a translation without her authorization. In the conclusion to the court's opinion, Grier wrote,
\end{abstract}

By the publication of Mrs. Stowe's book, the creations of the genius and imagination of the author have become as much public property as those of Homer or Cervantes. Uncle Tom and Topsy are as much publici juris [public property] as Don Quixote and Sancho Panza. All her conceptions and inventions may be used and abused by imitators, play-rights and poetasters. They are no longer her own - those who have purchased her book, may clothe them in English doggerel, in German or Chinese prose. Her absolute dominion and property in the creations of her genius and imagination have been voluntarily relinquished. All that now remains is the copyright of her book; the exclusive right to print, reprint and vend it, and those only can be called infringers of her rights, or pirates of her property, who are guilty of printing, publishing, importing or vending without her license "copies of her book." A translation may, in loose phraseology, be called a transcript or copy of her thoughts or conceptions, but in no correct sense can it be called a copy of her book. $(208)^{1}$ 
Not surprisingly, copyright and history of the book scholars often quote this conclusion, with its startling and puzzling image of Tom and Topsy ludicrously dressed in the "clothes" of German and Chinese language; but they often quickly dismiss the court's holding as an inexplicable aberration or as an example of the immaturity of the copyright law in $1853 .^{2}$

This essay analyzes the case in depth from a number of perspectives, taking Stowe v. Thomas seriously as a source of historical knowledge about copyright, authorship, Harriet Beecher Stowe, and her novel that might otherwise remain inaccessible. What can the case tell us about authorship and the copyright law in 1853 ? How did the law allocate power between authors and readers? What exactly was the nature of the author's property right under the copyright law? And how did these issues come to be resolved in a legal opinion that metaphorized these questions as a dispute over the right to control the exploitation of slave bodies?

In the context of Stowe v. Thomas, Stowe asserted rights to her work as an immaterial product of mental labor, and that claim to an immaterial literary property could have, if successful, given Stowe greater power and authority as an author and proprietor. Not only could others not appropriate her words as they appeared on the physical pages of her book, argued Stowe, they also could not adapt the immaterial, incorporeal essence of her work by dressing it in new material forms. The case proved to be a legal dead-end (the court denied Stowe the expansive proprietary rights she sought, and no other author seems to have had the cause, desire, and means to pursue a similar claim before the U.S. Congress amended the copyright statute in 1870 to give copyright owners the right to control translations of their works), but Stowe's failure is nevertheless revealing and instructive. By filing suit, Stowe attempted to enlarge dramatically the legal domain of the author in American copyright law, giving authors more powerful proprietary rights and the possibility of greater profits at the expense of readers.

I focus particularly on the central paradox of Stowe's situation laid bare by Grier's legal opinion - that Stowe, a woman who often presented herself and her authorship in self-effacing, maternal terms, is revealed in the context of Stowe $v$. Thomas to be an agent in the literary marketplace attempting to assert and police a property claim in her literary characters (figuratively, the children of her brain). If, as she often claimed, "God wrote the book," 3 what was she doing in court defending her absolute right to sell Tom and Topsy? Before analyzing the legal opinion and the factual circumstances surrounding the case, I first explore debates concerning copyright and authorship contemporary to the case. Finally, in addition to considering how the law regulated the circulation and consumption of Stowe's literary text, I link these concerns of the "outside" of Stowe's novel to her production of the "inside" of the novel by suggesting that Stowe's ruminations on the property status of slaves in Uncle Tom's Cabin can be understood, at least in part, as encoding anxieties about the relationship between an antebellum woman author and her literary property. 


\section{"AUTHORSHIP IS NOT ALL IN THE WORLD OF LETTERS": STOWE AND THE SITUATION OF THE AMERICAN AUTHOR UNDER THE COPYRIGHT LAW}

It was not until the 1850s that an American author's copyright became a truly valuable property. The United States of the 1850 s represented the largest potential literary market ever to that time, with more literate adults than any other country. The large number of potential consumers, combined with advances in book-manufacturing technologies (steam printing presses, stereotype plates, case binding) and the advent of steam railroads to transport books quickly and inexpensively throughout the country made the true national "best-seller" possible for the first time. Whereas in the 1830 s and $1840 \mathrm{~s}$, a "good" sale of a fictional work was several thousand, in the $1850 \mathrm{~s}$, the standard for success became tens of thousands. Enabled by new technologies of book production and distribution, the U.S. sales of Harriet Beecher Stowe's novel Uncle Tom's Cabin, generally conceded to be at least 300,000 during the first year of its publication, far outstripped its closest competitors. ${ }^{4}$

Stowe received royalties from her publisher for the sale of those 300,000 volumes, ${ }^{5}$ but did her copyright give her the right to benefit financially from other uses of her plot and characters? In the context of the international copyright debate, copyright proponents focused their energies on securing for American authors in England and English authors in America the right to print and sell copies of an entire work. Such wholesale reprinting required no further literary labor, but instead required the labor of those involved in multiplying copies of the book (typesetters, press operators, binders). If an author has legally secured the right to make and distribute copies of a work, another person who simply makes and distributes more or less exact copies clearly violates the copyright holder's right; but what about others who somehow reshape or alter the work (as was the situation in Stowe $v$. Thomas), translating it into another language, abridging it, or adapting it from one form to another, from novel into play, or poem into novel, before making and distributing copies? And what if someone uses the work, but neither makes nor distributes physical copies of the copyrighted work (that is, what if someone reads or performs it or an adaptation of it before an audience) ${ }^{6}$ Should the author derive the benefit from these uses? How wide should the domain of the author under copyright law be? ${ }^{7}$

The extraordinary popularity of Uncle Tom's Cabin put Harriet Beecher Stowe in a position to raise exactly these questions. After Uncle Tom's Cabin sold more copies in England than in America, and probably sold more copies in England than any English novel ever had, no one could respond to pleas for Anglo-American copyright by asking, as Sydney Smith famously did in the Edinburgh Review in 1820, "Who in the four quarters of the globe reads an American book?" (79-80). As Eaton Drone remarked 
in his highly regarded 1879 Treatise on the Law of Property in Intellectual Productions, the copyright in Uncle Tom's Cabin was "one of the most valuable American copyrights" (455). ${ }^{8}$ Although exact circulation figures are impossible to determine, many authors, publishers, and readers around the world believed that more people in the world had read Uncle Tom's Cabin than any other fictional work previously published. In the words of the (admittedly partial) National Era at about the time Stowe filed suit against Thomas, Uncle Tom was "the book of the age - a work which has gone through more editions and translations, been more widely circulated, and has created more sensation and discussion than any work issued during the present century" ("Uncle Tom Abroad"). Thus, in the popular understanding, Stowe had more to gain than any other author by exercising her copyright and more to lose when the copyright law did not offer her protection. Stowe thus became an important figure through which the country debated the perceived successes and failures of the copyright law in serving the interests of American authors, readers, and publishers. ${ }^{9}$ Her spectacular success explains, in part, why she became the plaintiff in one of the very few 19th-century American copyright cases concerning a work of fiction - Stowe had a much more valuable interest to protect than most of her author peers.

But what exactly was the copyright law supposed to do for American authors like Stowe? Did authors have an inherent natural right that the law recognized? Or was the law a government grant of privilege designed to spur production for the benefit of readers? Did authors create something new and valuable that had never existed before? Or did they merely collect odd bits and pieces of preexisting material? In 1853, when Stowe filed suit, these questions were frequently and hotly debated in the American press because of continuing attempts to pass an international copyright law, and these American debates over the expansion of authors' proprietary rights through the grant of reciprocal copyright with other nations (particularly England) are a crucial context for understanding the significance of Stowe's claim in Stowe v. Thomas.

Spurred by a petition of British authors in Congress in 1837 and then by Charles Dickens's tour of America 1842 and his repeated public castigation of American publishers for their "piracy" of his works, American authors began organized efforts to petition Congress for an international copyright law in the late $1830 \mathrm{~s} .{ }^{10}$ In 1843 , writing anonymously as the President of the American Copyright Club, William Cullen Bryant decried the failure of the American law to accord literary property (in the form of foreign-authored works) the same protection as other forms of property: "Word and thought - the very element of a diviner life - made sacred, it remains for this country to say that the issues of the head shall have an acknowledgment when they come to us in the shape of books, at least as equal to the fabrics created by the hand" $(6-7) .{ }^{11}$ Although Stowe's thoughts about some of the specific copyright issues raised by the Stowe $v$. Thomas case have not survived, ${ }^{12}$ she did publicly take a stand on the 
international copyright issue. Like Bryant, she asked why the law did not accord her literary property the same protection as more material forms of property. After receiving a letter from an English publisher offering her to pay a royalty for every copy of his edition of Uncle Tom's Cabin (in return for her approval of designating his edition the "author's edition"), Stowe forwarded the publisher's letter to Horace Greeley of the New York Tribune with her own letter, asking, "Might a man honorably and justly seize on another's estate, because some legal imperfection in the title allowed him to do so? and is it any better to seize on the avails of his talents?" (Stowe, "Copyright"). ${ }^{13}$ Although Bryant and Stowe (and many other copyright proponents in the context of the international copyright debates) argued for stronger protection of literary property rights based on analogies to material property, such pro-copyright claims are often qualified and complicated by a recognition that literary property is both like and unlike material property, that the author's property should receive the same legal recognition as property as does a piece of fabric or a landed estate, but that the author's property is immaterial, and thus both a more elusive and a "higher" form of property. In Bryant's words, the "issues of the head" are "elements of a diviner life."

Scholars studying the history of European copyright law in England and Germany ${ }^{14}$ have linked the emergence of the author as proprietor in the law with the rise of Romanticism and its claims for the special status of the author as original genius, and their analyses of this dynamic illuminate the tension also confronted by American authors as they sought to define the nature of literary property and their legal status as creators and proprietors. As Martha Woodmansee argues in her essay "The Genius and the Copyright," in $18^{\text {th }}$-century Germany during the Romantic era, authors seeking to ground their claims of ownership in their works found it "necessary to show that this work transcends its physical foundation ... to show that [the work] is an emanation of [the author's] intellect - an intentional as opposed to a merely physical object" (443); in short, to show that a "writer" is an "author," an originator, founder, or creator, a singular genius rather than a mere craftsman who is only one of many contributing his labors to the manufacture of a book (429). In addition to supplanting the notion of the author as one of many craftsmen, the Romantics sought to supplant the other available neoclassical model of authorship, that of the author as "inspired - by some muse, or even by God" (427). As Woodmansee argues, rather than seeing themselves as vehicles or instruments of some "higher, external agency," they "internalized the source of that inspiration. That is, inspiration came to be regarded as emanating not from outside or above, but from within the writer himself" (427).

Mark Rose traces a different trajectory in England, where copyright emerged earlier as a regulatory scheme for the protection of publishers' interests. According to Rose, in the $18^{\text {th }}$-century, after the publishersponsored passage of the first English copyright law in 1710 (the Statute 
of Anne), a new class of professional authors, such as Alexander Pope, began to use copyright law for their own benefit, and a theory of literary property as immaterial developed alongside a notion of the work as property like any other property. As Rose notes, the analogy between literary property and a landed estate (precisely the analogy Stowe deployed in her demand for international copyright) "provided a comforting sense of weight and tangibility" to literary property, but the discourse of literary property simultaneously "was moving away from its old foundation in the materiality of the manuscript as an object" (Authors and Owners, 58). In the case of Pope v. Curll (concerning the unauthorized publication of Alexander Pope's manuscript letters), "the notion of the essential immaterial nature of the object of copyright was born" (60). Through the process of litigation and further legislation, inquiries concerning the nature of literary property came to center "on the same pair of terms, the author and the work, a person and a thing. The complex, social process of literary production - relations between writers and patrons, writers and booksellers, booksellers and readers - became peripheral," thus "[a]bstracting the author and the works from the social fabric" (88). ${ }^{15}$

However, as Meredith McGill has persuasively argues in her examination of America's first Supreme Court copyright decision, Wheaton v. Peters (an 1834 case concerning an abridged edition of the official compilation of U.S. Supreme Court decisions), the American law did not "inherit" unaltered the English law's "concern with individual rights in texts" (21). Instead, the American law focused precisely on that social fabric from which the English law had abstracted the author, seeing private property claims to printed texts as an encroachment on the public's right to have unrestricted access to all printed texts:

Wheaton $v$. Peters established going-into-print as the moment when individual rights give way to the demands of the social, and defines the private ownership of a printed text as the temporary alienation of public property. It is with the circumscription of individual rights and not with their extension that nineteenth-century American copyright law is primarily concerned. $(21-22)^{16}$

As the many petitions to Congress, Congressional reports, and periodical articles and editorials of the period concerning the subject of international copyright amply demonstrate, authors and their interests were not central to American copyright law in 19th-century America, and attempts to reshape American law to make authors' proprietary rights central were met with well-organized resistance. The object of the law remained protection of the interests of American manufacturers who reprinted English books without permission and without paying royalties, and the preservation of resulting low book prices so that American readers could purchase and consume those American-manufactured (although not American- 
authored) books. In the words of the 1873 Senate report recommending against the passage of an international copyright bill,

Authorship, standing by itself, although the essential element, still, it is not all in the world of letters, and cannot in any measure, having at heart the interests of literature, be considered as standing independent by itself. If it be conceded to be the soul of science, it is essential that its productions should be embodied in books, and these involve the varied skill, industries and cunning workmanship of many hands, and at last, and not the least important agency, the enterprise, capital, and address of the publisher through whom these books are to be introduced to the reading public. (United States, 4)

In Woodmansee's and Rose's narratives of the development of copyright in Europe, the proprietary author of copyright supplanted just such definitions of the book as a material object created by many, rather than an intentional object, dependent for its existence solely on the author; ${ }^{17}$ but in the 19th-century American legal context, the author had not ascended to the peak of Romantic agency, presiding over and rationalizing the functions of all other actors in the production, circulation, and consumption of literary works. Stowe and other American authors trying to negotiate their own symbolic and legal authority thus found themselves contending with conflicting and contradictory discourses of authorship: their arguments in favor of the expansion of copyright demonstrate that they knew the limits of their position under the American law, but they also often gestured toward the more expansive symbolic powers and the legal proprietary rights for authors potentially underwritten by the Romantic ideology of authorship.

Arguments over which mode of authorship should prevail in the American law, the author as subsidiary and unimportant or the author as transcendent and all-encompassing, most often arose in the debates over international copyright, but at least one commenter, Henry Carey, understood Stowe's claim in her suit against F. W. Thomas to raise exactly these issues. Carey was the heir to a prominent Philadelphia publishing house, but he retired from the everyday business of running the firm to become a political economist. In 1847 , he became a staunch protectionist and advocate of the tariff and, in the $1850 \mathrm{~s}$, he lent his voice to an influential group of men involved in the Philadelphia book trades who opposed international copyright. ${ }^{18}$ In 1853 , just before Grier issued his decision in Stowe v. Thomas, Carey published Letters on International Copyright, which became a touchstone of the anticopyright position until the $1880 \mathrm{~s}$, when copyright proponents and opponents entered into a collaboration that enabled the passage of the 1891 International Copyright Law. ${ }^{19}$ In Letters, Carey specifically takes note of the Stowe $v$. Thomas case, without directly naming Stowe: "In this country, the only attempt that has yet been 
made to restrict the right of translation is in a suit now before the courts, for compensation for the privilege of converting into German a work that has yielded the largest compensation that the world has yet known for the same quantity of literary labor" (37). ${ }^{20}$ In consonance with his overall argument, Carey sees the "right" of translation as belonging to the public, rather than to Stowe, and he thus sees Stowe's suit as an attempt to "restrict" that right. He implies that Stowe had already been more than adequately compensated for her labor, and that she should not be able to prevent others from producing their own translations, in effect asking for more compensation even though she would not labor for that additional compensation. In Carey's view, the only justification for the grant of copyright to authors is to give incentive for authorial production that will benefit the public, so an author who labors little, produces a bad product, or whose work does not truly benefit the public should not be granted a copyright at all.

In fact, in Carey's view, almost all fiction writing falls into this category of labor that is not entitled to compensation. Referring to the works of Scott, Irving, and Dickens, Carey claims that they all made "no contribution to knowledge" (24), that a literary author merely "collects a great number of facts that he has dressed up in different forms" (25). Those facts and ideas, says Carey, belong in the first instance to the public, and an author who writes a book is like a man who creates a bouquet from flowers in someone else's garden. Only great scientific and philosophical men who create new ideas and new knowledge, argues Carey, actually grow new flowers, and copyright does not protect those ideas.

Although Carey's main target is a proposed copyright treaty with England, he also implies that all copyright is an illegitimate imposition on the rights of the reading public. Considering this imbalance between the rights of authors and readers caused by copyright, Carey predicts a time in the future when the public will no longer tolerate a monopoly given to bouquet gatherers who perform only the slightest labor in return for that monopoly. Scornfully addressing authors, Carey asks,

Can it be supposed that when, but a few years hence, our population shall have attained a height of fifty millions, with a demand for books probably ten times greater than at present, the community will be willing to continue you a monopoly, during forty-two years, of the right of presenting a body that is common property, as compensation for putting it in a new suit of clothing? (32)

According to Carey, the forty-two-year monopoly on the right to print and sell copies of a work that copyright granted an author in 1853 (a twentyeight-year first term, and the right to renew the copyright for a fourteenyear second term) was too much compensation. The public owed a fiction writer little or no compensation for these trivial (and implicitly feminized) activities of arranging thoughts into bouquets or dressing those thoughts 
in "clothing" of language. In examining the specifics of the literary field in 1853, Carey specifically cites Stowe as an example of the principle that "[t]he whole tendency of the existing system is to give the largest reward to those whose labors are lightest" (36). Rather than forty-two years of monopoly, says Carey, Stowe and writers like her deserved only a year's worth of copyright for their labors.

\section{"A CHANGE OF LINGUISTIC DRESS": STOWE V. THOMAS AND THE LAW OF COPYRIGHT INFRINGEMENT}

Stowe's attempt to enforce her copyright in her lawsuit against F. W. Thomas, the Philadelphia publisher of the German-American newspaper Die Freie Presse, is remarkable in a number of ways. ${ }^{21}$ Stowe's often domestic, self-effacing authorial persona, particularly her widely publicized self-descriptions of her composition of Uncle Tom's Cabin, make her an unlikely plaintiff. Stowe's claim that "God wrote" Uncle Tom's Cabin aligns her with a pre-Romantic mode of authorship through external inspiration; the multiple (and often contradictory) accounts of her composition of the novel deemphasize her role as originator, instead emphasizing the mimetic nature of the novel, both in the sense that the novel is meant to represent reality accurately and in the sense that she was a mere copyist, transcribing a vision that did not originate with her. Her accounts also consistently represent her writing as a form of domestic production for which her children were the first audience. In these domestic and maternal scenes, Stowe is not the Romantic author and agent creating and originating the novel from within herself. Instead, in another sense of the word agent, Stowe describes herself as merely an agent of some force beyond her control rather than as a subject acting independently. As she wrote to the Earl of Shaftesbury while she was compiling the Key to Uncle Tom's Cabin, "If they call the fiction dreadful, what will they say of the fact, where I cannot deny, suppress, or color? But it is God's will that it must be told, and I am the unwilling agent" (quoted in C. Stowe, 174). ${ }^{22}$

Copyright law, however, grants property rights as a reward for creative labor, and if she was a pre-Romantic author who was "inspired" rather than a Romantic author who was herself a God-like creator, then what happened to her legal authority? In the 1907 edition of Christian Science, Mark Twain ridiculed Mary Baker Eddy for her claim that God wrote her book, the scripture of the Christian Science movement, Science and Health. Eddy reported in her autobiography that she had sued to protect the copyright in the book and, in his critique, Twain wonders how, if she was "merely an amanuensis, and furnished neither the language of Science and Health nor the ideas" (143), she could claim copyright in the book? Concludes Twain, "[T]he Deity was the Author of the whole book, and Mrs. Eddy merely His telephone and stenographer" (144). ${ }^{23}$

Also remarkable is that Stowe had a legally valid copyright in Uncle 
Tom's Cabin to even attempt to enforce at all. Stowe publicly and privately protested that commercial and financial success came to her unbidden, for instance, writing in a famous letter to Eliza Follen that she wrote Uncle Tom's Cabin "just because [she] could not help it," and that the first royalty check for $\$ 10,000$ was an "agreeable surprise, totally unanticipated and unsought" (quoted in Fields, 176). However, Stowe's actions immediately prior to publication reveal her sophistication and aggressiveness in managing her career and protecting her interests. While claiming not to plan for the novel's success, she took the rather unusual step of registering the copyright in her own name before serialization in the National Era began. Without this piece of legal forethought and planning, Stowe would not have been in a position to file suit because proper registration of a copyright before publication was a necessary precondition to legal recognition of her literary property rights. ${ }^{24}$ Because Stowe had registered her copyright and thus possessed a property that the law was obliged to protect, the court had to define the nature of that property and rule on whether Thomas's translation infringed her property right. In the international copyright debates, copyright proponents often argued for the materiality of the work because basic legal recognition of literary property as property when it crossed national boundaries was the primary issue. Even in many 19th-century copyright cases before Stowe $v$. Thomas (including Wheaton v. Peters), the legal disposition of competing claims often rested on an initial determination of whether the plaintiff possessed a property that the law was bound to protect at all (In Wheaton v. Peters, the court held that the plaintiff had failed to fulfill all of the requirements for registration, and thus the question of whether defendant's abridgment was an infringement was irrelevant. ${ }^{25}$

Even though Stowe's copyright registration put her in a position to file suit, the question of copyright and translation was by no means a settled point of law in 1853, and Stowe could not have assumed that the outcome of her suit was a foregone conclusion. In the only extensive commentary on the case in the English-language press, an anonymous contributor to the weekly New-York Tribune in April 1853 (shortly after Stowe filed suit) both supported Stowe's claim on principle and acknowledged that her case under the American statute was weak. "As for the absolute moral right," he writes, "we see nothing in the nature of things to limit the ownership of the author. It is his [sic] work and ought to be the essential right of the case, - which is legitimately subject only to such limitations and conditions as Society, acting for the general welfare, may see fit to establish" ("'Uncle Tom' at Law"). Nevertheless, he concedes, "[I]t is far from certain that our legislation is such as Mrs. Stowe's complaint against Mr. Thomas would seem to suppose ... the case is not directly foreseen or provided for by the statute; and unless Mrs. Stowe's position can be established inferentially from its spirit, or from the construction of some hitherto unnoticed phrase in its language, the Court will have to decide against her." Foreseeing this outcome, the author calls for a revision of the copyright statute so that it would conform with moral principle. ${ }^{26}$ 
As the Tribune predicted, Justice Robert Grier followed the most conservative school of thought in his ruling. Quoting the famous English copyright case Millar $v$. Taylor, ${ }^{27}$ Grier asserts that the whole right of the author in his ${ }^{28}$ work "rests upon the foundation of the property in his copy" (207). Elaborating on the meaning of "copy," Grier states,

A "copy" of a book must, therefore, be a transcript of the language in which the conceptions of the author are clothed; of something printed and embodied in a tangible shape. The same conceptions clothed in another language cannot constitute the same composition; nor can it be called a transcript or "copy" of the same "book." (207) 29

That is, the author's right in a work of literature is restricted to the words on the page: copyright does not protect elements of plot and characterization, which might be appropriated by another but then described in other words than those the author chose. To expand on Grier's use of this common copyright metaphor of language as "clothing" ideas (a metaphor Carey also uses in his critique of copyright), the nature of the work protected by copyright is merely material, like clothing; literature is a linguistic article of manufacture, and the author has the right to control exact reproduction of those linguistic clothes in the form of words printed on the page. Although there is a body under that clothing, which the author created or conceived, the body becomes common property once the author displays it to the public dressed in language. If another person dresses that body in new linguistic clothes, he becomes an "author" in his own right.

Grier thus directly contravenes the arguments advanced by Stowe's lawyers, Samuel H. and Samuel C. Perkins, a father-son team of Philadelphia lawyers, ${ }^{30}$ and the opinions of the author of America's first copyright treatise, lawyer George Ticknor Curtis. In their arguments on her behalf, Stowe's attorneys claim,

An author is the "creator," the "efficient cause of a thing." 31 In respect to a book, he is the creator of the ideas - the thought the plan - the arrangement - the figures - the illustrations the argument - the style of expression. The exclusive right to sell these is what is secured by copyright. The right is original, inherent; a right founded on nature, acknowledged, we think, at common law; a right which stands on better ground and is more deeply rooted than the right to any other property. Now, a translation is an infringement of this right. [citations omitted] (202)

As authority, Stowe's lawyers cite George Ticknor Curtis's 1847 A Treatise on the Law of Copyright. Curtis, who was a published author of several legal and political treatises in addition to his copyright treatise, strongly 
advocates an expansion of authors' rights under copyright. ${ }^{32}$ In particular, he expresses a strong opinion in favor of international copyright, and he takes on the current state of the law with respect to abridgments, which he considers "contrary to principle" (vii). Consonant with the Romantic view of the author as creating an intentional object and owning that object in its immaterial form, Curtis sees literary property not as material, but as "incorporeal": "When we consider the incorporeal nature of literary property, it will be apparent that no writer can make and publish an abridgment, without taking to himself profits of literary matter which belong to another" (276). He further sees the right to abridge a work to be part of the author's right "to avail himself of the profits to be reaped from all classes of readers, both those who would purchase his production in a cheap and condensed form, and those who would purchase it in its more extended and costly shape" (278). That is, the author's property right is in his incorporeal creation, and that right includes the right to give that incorporeal, immaterial creation different material shapes by changing its linguistic dress.

Curtis extends the same logic of the author's Romantic agency that he uses in his critique of the law on abridgments to his critique of the law on translation. He notes that there had been no American cases on translation, and that the English decisions all involved translations of works that were in the public domain (either because of the age of the original work [i.e., works of classical antiquity in Greek or Latin] or because the original work was work by a non-English author not entitled to copyright protection in England). According to Curtis, these cases "merely tend to show that the act of translation, by giving a new dress to the work, incorporates with it the pains and labor and learning of the translator" (292), thereby giving the translator a copyright in the translation. In 1847, no cases presenting facts analogous to the Stowe $v$. Thomas case had yet arisen, but Curtis opined as to what he believes should be the reasoning used to decide such a case:

[T] he new language in which [the author's] composition is clothed by translation affords only a different medium of communicating that in which he has an exclusive property; and to attribute to such a new medium the effect of entire originality, is to declare that a change of dress alone annihilates the most important subject of his right of property. It reduces his right to the narrow limits of an exclusive privilege of publishing in that idiom alone in which he first publishes. (293)

The only issue decided in Stowe v. Thomas was whether the translation Thomas published infringed Stowe's copyright. That is, Thomas did not deny that he had published a translation, nor did he assert that Stowe did not have a valid copyright in Uncle Tom's Cabin. In fact, Thomas's attorneys cheerfully conceded in their arguments that Thomas and his trans- 
lator, Adolf Strodtmann, appropriated Stowe's entire work. ${ }^{33}$ The question, as posed by Thomas's attorneys, "cannot be how much we have taken, for we have taken all; nor how much we have added, for we have added nothing: but only how have we taken, and what have we done with it?" (205).

What they had done with it was translate it into German, and that translation, so they argued, was not an infringement of Stowe's right to multiply her copy. Judge Grier accepted this view. Although he conceded (as Henry Carey did not) that Stowe did create the novel's "conceptions and inventions," he found that her conceptions and inventions had no status as property once she published her book. Because they had no status as property, she could not prevent others from selling them as long as those others contributed their own labor in dressing her immaterial conceptions in new, concrete linguistic dress. Tom and Topsy were "the creation of the genius and the imagination of the author" - out of her imagination, in a God-like act of creation, she had brought new souls into the world - but she had property rights only in the words ("the language in which the conceptions of the author are clothed") that she used to describe those "souls." Clearly, if Grier had accepted Stowe's arguments and followed Curtis's lead, giving her property rights in the incorporeal "souls" of her novel, Stowe would have prevailed; Thomas would have been permanently enjoined from publishing the German translation and would have been forced to surrender his profits to Stowe.

Stowe was not concerned, however, with stopping publication of the Thomas translation merely to protect an abstract or symbolic right, but with protecting the market for her own translation. She had a clear economic interest in preventing Thomas from publishing his German translation as her affidavit filed in the suit makes clear. The first installment of Thomas's translation appeared in Die Freie Presse on January 1, 1853. In 1852 , Stowe, uniquely positioned to exploit such an opportunity because of Calvin Stowe's strong German language skills and connections to German academic culture, commissioned her own authorized German translation of Uncle Tom's Cabin from Professor Hugo von Hutten, for which she obtained a copyright in her own name. Strong abolitionist sentiments in the German-American community and the large number of German-language speakers, both recent immigrants and more established immigrants and their descendants, who continued to speak, read, and write German, made German the most obvious and profitable target for a translation to be marketed within the United States. ${ }^{34}$ By early 1853 , her publisher, John P. Jewett, was advertising that that translation would be available in March of $1853 .{ }^{35}$ As Stowe's affidavit explains, she was "in hopes and reasonably expected to receive large profits from the sale" of the authorized translation and stood to be "greatly injured" in respect of what she saw as her "sole right" to exploit the market for translations for sale in America (Stowe v. Thomas, Manuscript, affidavit, 5). In addition to the German translation, Stowe had already authorized a Welsh translation, 
which was published by Robert Everett for the " 100,000 Welsh emigrants in this country" (Wilson, 331). ${ }^{36}$ To return to George Ticknor Curtis's analysis of copyright in translations, although the author's property may be incorporeal, legal title to that incorporeal property grants power in the marketplace; the person who holds title to that incorporeal property has the sole right to multiply material "copies," which can be sold on the market as commodities. At stake was the right to exploit fully all sectors of the market, and Stowe, living in a large, highly literate, multilingual country, attempted to do just that: to expand the legal concept of author's property far enough to give her, as an author, the right to exploit all segments of the (American) market, whether or not they were English speaking. ${ }^{37}$

With the exception of the Tribune article, the English-language press, unlike the German-language press, took only cursory note of the suit and Grier's opinion. To the English-language newspapers in Philadelphia, the case was a piece of legal arcana that even Stowe's celebrity status could not make of interest to the general public. ${ }^{38}$ The failure of the Philadelphia press to give serious attention to the case certainly did not arise from a belief that the copyright law had no relevance or interest for its readers. For instance, after failing to report the decision even in its coverage of the local courts, the Public Ledger prominently featured an anti-international copyright editorial on December 27th, 1853, denouncing proponents of a copyright treaty between England and America being considered by Congress for failing to consider the public interest: "The State has invariably denied the literary man's right per se, by stepping in to determine what rights society, for its own good, could concede him. Here, in fact, lies the gist of the question. The public, as well as the author, has rights in this matter" ("Copy-Right Treaty").

In short, the English-language press could not see that Stowe $v$. Thomas had important public policy implications because the Englishspeaking and English-reading public's interests were not directly involved. (Even the New-York Tribune article treats the question as a relatively arcane one of legal interpretation rather than as a likely focus of popular public interest.) The German-language press, however, recognized that Stowe's claim against Thomas represented an attempt to expand the private property rights of authors to the possible detriment of the German reading public. ${ }^{39}$ The German-American press was outraged that Stowe claimed the right to make her translation the only one available, or to prevent the publication of a translation altogether. That is, they recognized that copyright law gives the copyright owner both the right to control the multiplication and distribution of copies of the copyrighted work and the right to refuse to allow the work to be multiplied and distributed. The New-Yorker Staats-Zeitung, one of the most widely distributed German newspapers in America (Levine, 171), indicated the potential popular interest in the case by giving the space on the front page of its Sunday edition normally devoted to popular serial novels to an article on the suit. Otto Reventlow described the case as "not only important for book dealers, but also more or less important to all "Germans" because a win 
by Stowe would give American authors too much power over GermanAmerican readers:

Should it depend on the arbitrary whim of a perhaps narrowminded, nativistically inclined author or publisher, whether works of American literature in good or indeed in any kind of translation should be permitted to reach a non-English-speaking public? The Anglo-American bookseller, who possesses a readymade public in all parts of the United States, has the right to reprint the whole of European literature, German, English, French, etc.; - should only the German-American bookseller, whose public... must be collected and established, not be granted the right to make Anglo-American literature available to his compatriots through good-quality translations? (Reventlow and Becker, 205-6)

The question of the quality of the competing translations is central to Reventlow's analysis because he believed that Stowe was attempting to force a bad translation on German readers. Cataloging what he considered to the horrors of Stowe's translation, "entirely un-German expressions, grave language mistakes, or other irrefutable flaws" on "every page" (2078), Reventlow argues that translations should be allowed to compete on the market so that readers can choose according to their own tastes. As Thomas's lawyers later conceded in court, the sale of Stowe's own translation was "impaired" by Thomas's publication of the Strodtmann translation, but only because "her translation has less genius than ours" (206). Readers had been given a choice, and they had chosen to purchase the translation published by Thomas, not that authorized by Stowe.

The New-York Tribune reported with mild approbation that Stowe had refused a settlement proposed by Thomas (the terms undefined), suggesting that her refusal probably resulted from a wish to establish a legal principle. Reventlow and other German-Americans gave this refusal central emphasis in their attacks on Stowe's character. ${ }^{40}$ Reventlow, reporting details not included in the Tribune article, claims that "Mr. Thomas offered (merely in order to avoid the scandal of such a lawsuit) an extremely favorable settlement to Mrs. Stowe, in which he offered her the publication rights of his translation as a gift, if she were to abstain from the lawsuit." "What light," he asks the "public," does her insistence on continuing with the lawsuit "shed on the character of the 'pious' and 'Christian' Mrs. Stowe?" (206). In a pointed attack on Stowe's piety, Reventlow quotes extensively from Stowe's affidavit in the case, in which she "swears" to the high quality of that translation, and accuses her of false swearing. "Either Mrs. Stowe understands absolutely no German," he writes sarcastically, "in which case she gave an oath very frivolously on a subject, where she knowingly was in no condition to be a judge, or she understands German, in which case she gave an oath even more frivolously false" (209).

To Reventlow and his German-speaking brethren, F. W. Thomas and 
his translator were not faceless figures notable only because they incurred Stowe's wrath. They were important agents of German language and culture in America - agents whose ability to do this important work could be destroyed if Stowe's claim succeeded. As the New York correspondent of Atlantis, a monthly German-language magazine published in Detroit, complained,

Madame Stowe, bathed in tears and with her eyes turned towards heaven, indeed swears that this translation is good, and this the world must believe, and Herr Thomas is perhaps headed for ruin if he must pay thousands of dollars to the courageous, heroic author who promotes the universal rights of man. (Letter, 159)

The disinterested woman who used the power of emotion and tears to convert American readers to abolition is here transformed into a woman using meretricious tears to veil the commercially interested motives behind her attack on F. W. Thomas.

\section{MRS. STOWE SELLING TOM AND TOPSY: THE PECULIAR ROLE OF ABOLITIONIST POLITICS IN STOWE $V$. THOMAS}

My discussion of the case thus far has focused on the copyright issues at stake, but other factors may have weighed heavily in the final outcome. Stowe's authorial agency with respect to Uncle Tom's Cabin was, of course, intimately tied to the abolitionist message of her novel, and her commercial interest in the exploitation of her characters potentially conflicted with her abolitionist critique of capitalist market economics. The Atlantis correspondent's parting shot in his invective against Stowe brings this conflict into sharp focus:

Thus does an American abolitionist propagate her teachings. Will we in Europe finally realize that this abolitionism, at least the whining pietistical abolition of Mrs. Stowe, is a humbug and a money business, like Barnum's Sea Tiger or Tom Thumb? (Letter, 159)

That is, Stowe, like P. T. Barnum, made a business of selling characters to the public, and despite her claims to moral and ethical purity of purpose, she ruthlessly attempted to harm her German-American competitor. Rather than incidentally using the sale of her book to promote abolitionism, claim her German-American critics, Stowe used abolitionism primarily to sell her book.

The attack on Stowe in the German-American press presents the 
strange spectacle of abolitionists attacking the world's most famous advocate of abolition. August Becker, who wrote a companion piece attacking Stowe's suit that appeared alongside Reventlow's in the Staats-Zeitung, was, like many intellectuals who fled the failed revolutions of 1848 in Germany, a staunch abolitionist, dedicated to the ideology of "free labor and free men" (Zucker). The editor of Atlantis, Christian Esselen, was also a radical Forty-Eighter (Zucker), and the anonymous article on Stowe $v$. Thomas published in the Atlantis is careful to attack not all abolition, but the "whining pietistical sort" practiced by Stowe. F. W. Thomas emigrated from Germany in 1837 and thus missed the revolution, but his abolitionist politics were similar (his abolitionism clearly motivated his initial decision to make Stowe's novel accessible to German-Americans), and he would soon officially affiliate Die Freie Presse with the new national Republican Party (Fones-Wolf and Shore, 64-65; Wittke, 41-42, 84, 141). In contrast, the Staats-Zeitung, affiliated with older established commercial interests in the New York German community, was conservative and anti-abolitionist (Levine, 171; Wittke, 79-82, 138; Nadel). Nevertheless, abolitionist and antiabolitionist forces within the German-American community, even if they did not agree on the abolitionist message of Stowe's novel, joined forces to attack her abolitionism as meretricious and her lawsuit as a commercially motivated assault on the rights of GermanAmerican readers.

The remarks by the German press bring us back to the extraordinary image in Justice Grier's opinion of Tom and Topsy being "abused" by "those who have purchased [Stowe's] book." What is implied in Grier's opinion is made explicit in the German press's account - that Stowe, the abolitionist author, had profited by "selling" her slave characters to the public; but as Grier held, once she had sold them, they and their labors no longer "belonged" to her. They "belonged" to the public at large, which could do with them as it chose.

What are we to make of Grier's metaphorizing that part of the work that Stowe does not own as her slave characters? On the strictly abstract level of legal analysis, the metaphor reveals a serious flaw in the copyright metaphor of language as clothing. The metaphor both implies and denies a body underneath the linguistic clothing - it implies a body because clothing by definition covers bodies, but the purported logic of the analogy also denies the presence of a body because language is supposed to be material or corporeal, and the ideas, conceptions, and inventions that are "clothed" by language are supposed to be incorporeal. In a visually stunning but wholly illogical metaphor, then, Grier makes the naked circulating bodies of Stowe's characters represent Stowe's incorporeal creations.

Whatever the logic (or illogic) of making the bodies of Stowe's characters stand in for her "conceptions" and "inventions," Grier crucially asserts that Stowe cannot control their circulation after she publishes her book: "All her conceptions and inventions may be used and abused by imitators, play-rights and poetasters. They are no longer her own - those who have 
purchased her book, may clothe them in English doggerel, in German or Chinese prose." To some extent, Grier simply describes here the actual result of Stowe's limited control under the copyright law over the appropriation by others of her fictional characters: Uncle Tom and Topsy were used and abused by poetasters, who wrote bad verses about them, and particularly by playwrights, who produced many dramatic adaptations of the novel that made Tom and Topsy the objects of comic scorn rather than Christian compassion. However, Little Eva, Stowe's saintly white child heroine, was also commercially exploited by those same playwrights and poetasters (the playwrights particularly delighted in having Eva physically ascend to heaven before the eyes of playgoers), but Grier does not make Eva a character in his legal drama in miniature. One might also identify Grier's dramatic tableau as an accurate depiction of what Saidiya Hartman calls a "scene of subjection" fundamental to chattel slavery in the United States. As Hartman argues, legal prohibitions against the black slave's self-defense against white abuse encoded "the submission of the slave to all whites... Since the subjection of the slaves to all whites defined his condition in civil society, effectively this made the enslaved an object of property to be used and abused by all whites" (24). Further, as Hortense Spillers argues, the passage of the Fugitive Slave Law made the slave "as much the 'property' of the collusive state as he or she was the personal property of the slaveholder" (545).

Still, legal logic and analysis simply cannot persuasively account for Grier's extremely peculiar invocation of Tom and Topsy in the opinion, but the manuscript version of Grier's opinion reveals an interesting earlier version of a key sentence that suggests a possible extralegal logic driving Grier's choice of the metaphor and even his ultimate holding against Stowe in the case. In the manuscript, in place of the published sentence that begins "All her conceptions and inventions may be used and abused," Grier first wrote the beginning of a sentence that he crossed out and chose not to continue: "They may be made the heroes of poems." Grier seems to have decided that use and abuse were more appropriate to Tom and Topsy than heroism, despite the fact that Tom is clearly Stowe's intended hero (she even identifies him as "the hero of our story" in the novel's first description of him [68]). Even though Stowe created Tom and Topsy, the court will not step in to prevent the abuse of them. Instead, "those who purchase her book" may dress Tom and Topsy in new linguistic clothes, even if those clothes are absurdly inappropriate and transform Stowe's characters into soulless and grotesque parodic figures divorced from her abolitionist intentions. Even though Stowe "created" Tom and Topsy, her intention to make them heroic is irrelevant because the public now owns them. Thus, in another peculiar turn of logic, Grier transforms Stowe's slave characters, persons whom, by definition, a particular free person claims title to as private property, into an emblem of public property - property that belongs to everyone and thus to no one person in particular. Despite the broader public ownership and subjection of all slaves to all whites noted by Hartman and Spillers, as Hartman also notes, "The few restrictions 
placed upon the use of the slave property concerned only the master's rights of property" (25), and it is precisely Stowe's property rights as "master" of her characters that Grier's scene insists on erasing and denying with his claim that she is no longer master because she has "sold" them.

Why would Grier choose this extraordinary metaphor to conclude an opinion that was essentially complete without it? (Indeed, not all reported versions of the opinion published in 1853 and 1854 include the sentences containing metaphor, an omission that underlines the metaphor's status as excess). ${ }^{41}$ Although intention is necessarily difficult to determine (and although judges are supposed to apply the law as it is to the facts before them, whatever the circumstances or personal feelings external to that determination), Grier and his court had good reason to want to undermine Harriet Beecher Stowe's authority, and Grier's opinion in Stowe $v$. Thomas may have been written with that goal in mind, whatever the merits of the copyright issues raised by the case. At the time of the Stowe $v$. Thomas decision, Grier's position on the abolition question was crystal clear. Grier's Third Circuit federal court was responsible for enforcing the Fugitive Slave Law of 1850. Congress appointed Grier as the Supreme Court justice for the Third Circuit in 1847 in part because he held the "approved" sentiments toward the responsibility of the courts for the return of fugitive slaves under the 1793 fugitive slave law. ${ }^{42}$ After the enactment of the 1850 law, Grier was one of the first circuit justices to be called upon to enforce the law, and although other circuit courts were active in enforcement, Grier's assignment to the Third Circuit made him one of the most active and vociferous judges in the enforcement of the law because of Philadelphia's role as one of the first Northern stopping places for fugitives and because of anti-Fugitive Slaw Law agitation and resistance centered in the city. Paradoxically, then, Justice Grier, a notable enforcer of the Fugitive Slaw Law, sat in judgment of Stowe's claim for enforcement of her copyright in a novel that is essentially a six-hundred-page plea for public resistance to the Fugitive Slave Law, a novel that in its serialized form ran concurrently in the National Era with detailed reports on Grier's handling of the so-called Christiana Riots case against free white men who aided fugitive slaves. ${ }^{43}$ Readers residing in the Third Circuit who took Stowe's novel to heart by imitating the actions of the members of the Byrd family (who self-consciously choose to violate state and federal law to assist Eliza and Harry in their escape) could have found themselves subject to prosecution in Grier's court. The German-Americans may have used the press to attack Stowe while not undermining the larger abolitionist cause, but Grier had clear motivation to use his opinion in the case to undermine both Stowe and the cause promoted by her novel.

The abolitionist message of Stowe's novel caused Grier to confront a choice much like that presented to 19th-century judges considering suits concerning obscene works, who were obliged by well-established common law principles to deny property rights to producers of pornography seeking suppression of unauthorized reproductions of their works, but who by that denial might allow for the wider circulation of obscenity. ${ }^{44}$ Grier had 
to choose between granting private property rights to Stowe in her characters (a holding that might have restricted circulation of Stowe's novel, but that would also potentially have allowed Stowe to earn more profits from it) and declaring her characters to be public property free for all to appropriate (a holding that promoted circulation and greater public access to Stowe's "conceptions and inventions" and the abolitionist message they carried). At precisely the time that Grier was writing his opinion in Stowe $v$. Thomas, one Philadelphia newspaper recognized the threat that wide circulation of Stowe's slave characters presented to Grier's authority as an enforcer of the Fugitive Slave Law: the Pennsylvania Freeman reprinted a satiric item from a Pittsburgh newspaper that "reported" an application for an injunction against performance of a theatrical version of Uncle Tom's Cabin had been made to Grier on the grounds that the play fostered abolitionist sentiment and encouraged violations of the Fugitive Slave Law ("From the Pittsburgh Despatch"). ${ }^{45}$ Grier, the legal guardian of the interests of slave owners, thus paradoxically encouraged the wider circulation of Stowe's abolitionist ideas by refusing to grant her an injunction against Thomas.

Although the decision against Stowe allowed for greater dissemination of Stowe's ideas, Grier's opinion also potentially undercut Stowe's moral authority by exposing an uncomfortable truth about Stowe's relation as an author to her work and to her literary characters - a relationship that is both protectively maternal and economically exploitive. By making Tom and Topsy the emblems of Stowe's "creations" and "conceptions," Grier brings to mind the classic trope of the (male) author's book as his child a child produced out of his brain rather than from a woman's womb. Although in one sense the novel as a whole is the author's child, Grier's use of the metaphor slides into a metonymic substitution of Tom and Topsy as characters for the work as a whole as her brainchild. Uncle Tom and Topsy are thus figuratively transformed into Stowe's children, and Stowe, their "mother," has willingly subjected those children to abuse by selling them. ${ }^{46}$

As a number of critics have noted, Uncle Tom's Cabin proposes maternity - a sphere of influence uncorrupted by commercial interests - as an antidote to the market and to trade. ${ }^{47}$ Stowe's authorial position of commercial power, her role as an author/mother selling her children in the literary marketplace, potentially threatened her moral authority and the sentimental project of her novel. As Gillian Brown argues, the families in Stowe's novel operate according to an economic model, even if that model is not a market model, and white women assimilate slaves into the human community by owning them in the same way that they own their own white children:

Stowe replaces the master-slave relation with the benign proprietorship of mother-child, transferring the ownership of slaves to the mothers of America.... [S]laves are synonymous with 
children because they lack title to themselves and need abolitionist guardianship - which is to say, maternal aid. . . By imitating God's parental economy, mothers approximate heaven in their homes. (32)

As Brown makes clear, however, mothers may own the fugitive slaves under their care and their own (white) children, but this proprietorship is stripped of the moral taint of slave ownership because it is not commercially interested. The mothers of America will not sell their children, white or black. Grier's opinion in Stowe v. Thomas thus cleverly uses the scene of Tom and Topsy's abuse to suggest that Stowe has violated the values so passionately promoted in her own novel - she has "sold" Tom and Topsy, her brainchildren, depriving them of her maternal guardianship and exposing them to use and abuse. By incorporating the characters of the novel into his opinion, Grier, an apologist for slavery, effectively turns Stowe's own characters and her novel's moral critique against her. His opinion seemingly encourages public "use and abuse" of Tom and Topsy while also suggesting that Stowe herself is responsible for this abuse of slaves because of her own commercial interests in and exploitation of them in the marketplace.

\section{WHO HAS "TITLE" TO TOM? UNCLE TOM'S CABIN AS A PARABLE OF LITERARY PROPERTY}

Grier's reading of Stowe's authorial situation does not merely expose a scene external to the novel and contradicting the novel's values; it also uncovers concerns deeply embedded in the novel's narrative. Concerns about her conflicting roles and about the limits and possibilities of authorial property rights were part of Stowe's "scene of writing." 48 I have argued that Grier metaphorized literary property as slave bodies to accomplish his antiabolitionist ends. However, even apart from the context of Grier and Stowe's conflict over the enforcement of the Fugitive Slave Law in 1853 , Grier's opinion suggests that we might fruitfully read Stowe's slave characters as particularly appropriate figures through which the author imagines her relationship to her literary work - the work is a person, the child to which the author gave birth and which seems to take on a human life of its own, but the work is also a thing, more particularly a property, that the author owns and can sell and that may also be "stolen" by others. Stowe's original subtitle for the novel, "The Man that was a Thing" (a title that was advertised in the National Era, but that was not used on any of the serialized installments), suggests just this combination of properties that make Tom a peculiarly suitable figure of Stowe's authorial property. ${ }^{49}$ This peculiar relation of authors to their works, which are both things and persons, is memorialized in the etymology of the word 
plagiarism, which is derived from the Latin word plagiarus, one who abducts the child or slave of another. As Grier's opinion suggests, the author is both mother and proprietor of her work.

Stowe's actions prior to the publication of Uncle Tom's Cabin show her keen awareness that her "child" was vulnerable to "abduction." Not only did she take care to register the copyright in the novel in her own name before serialization began, she also retained ownership of the copyright during its initial book publication, rather than transferring the copyright outright to the book publisher, as many authors did. She also knew that her own work was, as most literary works are, derived from others. She had herself "stolen" characters and plots from other works of fiction, from the minstrel tradition, from abolition tracts, and especially from slave narratives. ${ }^{50}$ The venue for which she originally wrote the novel, the National Era, was a political anti-slavery newspaper that juxtaposed extensive coverage of Fugitive Slave Law cases and other news items concerning the legal and political aspects of the slavery controversy with fictional stories and tales (some about slavery, but many simply sentimental or humorous works designed for general family reading) ${ }^{51}$ The National Era was thus full of accounts of slaves who had, in a sense, "stolen" themselves from their owners, becoming fugitive property that Southern slave owners asked the courts to return to them. Such cases suggestively foreshadow Stowe's attempt in Stowe v. Thomas to have the courts return her fugitive literary property to her.

What I am suggesting, then, is that the novel's anxiety about the status of slaves as property and the vicissitudes and abuses to which slave property is subjected reflects, in part, Stowe's anxiety about authorship and about her own role as a proprietor of her literary work. What was to be the fate of her own work and her literary characters? If her "property" escaped her control, would the courts return control to her? Could she prevent others from "abducting" her characters? What were the possibilities and limitations of literary proprietorship under the copyright law in antebellum America? The central issue of Grier's opinion - who has "title" to Tom? - is also the central issue of the novel. Through its exploration of Tom's status as both person and property and particularly through its examination of Tom's relationships to his various owners, both human and divine, the novel explores Stowe's anxieties about the possible appropriation and exploitation of her slave characters, as well as the conflicts between Stowe's maternal values and her authorial proprietorship. If we read Tom as a figure of literary property, then each of his owners represents a possible model of authorial proprietorship. Although the novel attempts to construct a positive model of proprietorship in accord with the novel's maternal critique of the marketplace, the novel just as often exposes the limitations of authorship and Stowe's participation in market economics.

The novel begins, of course, with Tom's status as private property foregrounded as Mr. Shelby transfers Tom's title to the slave trader Haley in 
satisfaction of a debt. As Meredith McGill notes, on one level Grier's opinion implicitly analogizes Stowe's relation to her novel to Mrs. Shelby's relation to Tom at the opening of the novel - both Stowe and Mrs. Shelby are "helpless in the face of a slave transaction" (51). Mrs. Shelby wants to prevent the sale of her family's slaves, but her husband holds the legal and economic right to do so, and Mrs. Shelby, like Stowe, cannot prevent the use and abuse of Tom after he is sold. While secretly disapproving of slavery and of her family's role as slave owners, Mrs. Shelby has nevertheless tried to make slavery and her family's commercial interest in Tom and the other slaves disappear by treating them just like her children, as human creatures with souls. As she tells Eliza before she finds out that Mr. Shelby does indeed plan to sell Uncle Tom and Eliza's son, Harry, "I would as soon have one of my own children sold" (52). After she learns the truth, she realizes that her earlier efforts to humanize her slaves were futile, saying "I was a fool to think I could make anything good out of such deadly evil" (84). As the slave trader Haley tells Mr. Shelby, Tom's religious sentiments are a "valeyable thing in a nigger, when it's the genuine article" (42). By exercising a maternal and benevolent moral guardianship over her slaves, she has actually made them more valuable as property, suggesting also the paradox of Stowe's authorial position - the better she "raises" her characters, the more likely others are to want to appropriate them. As Walter Benn Michaels notes, however, the problem with the Shelby family ownership of the slaves is not primarily the status of the slaves as property, but the fact that property, by definition, is alienable that the slaves are subject to sale, seizure, and foreclosure like other property. If Mr. Shelby has a legally "perfect" title to Tom, then Tom is a perfectly alienable property, which Mr. Shelby can transfer to another at his will (or which can be taken from him against his will if he pledged his property to secure a debt and he cannot repay the debt).

Mrs. Shelby mothers the slaves under her care, but she does not give birth to them. Stowe, as an author, both "mothers" her characters and brings them into being; she is their creator and God as well as their guardian. Tellingly, the novel insists that we understand the relation between God and Tom as a sort of extraordinary property relation, thus encoding Stowe's fantasy of a truly perfect and inalienable title to her literary creations. While Mrs. Shelby's proprietorship fails, God's "ownership" of Tom does not fail. At many important junctures, the novel objects to Tom's commodification, the cruel irony of a man being turned into a thing subject to ownership and trade. For instance, the narrator expresses appropriate outrage at the objectification of Tom as he sits shackled among bales of cotton on his trip down river to Legree's plantation ("for even a legal enactment that he shall be 'taken, reputed, adjudged in law, to be a chattel personal,' cannot blot out his soul, with its own private little world of memories, hopes, loves, fears, and desires," [481]). But once Tom reaches the plantation, his ultimate defense against Legree is not that his soul is free, but that his soul is owned by God. When Legree claims that he owns 
Tom "body and soul," Tom answers, "No! no! no! my soul an't yours, Masr! You haven't bought it, - ye can't buy it! It's been bought and paid for by one that is able to keep it" (508). Tom here draws on the image of Christ in his role of the "Redeemer" who "bought" eternal life for mortal sinners with his blood shed on the cross. That is, Christ has purchased Tom's soul and freed him from bondage to sin and death (thus Stowe's title "The Victory" for the chapter in which Tom triumphs over despair and feels assured of his soul's salvation, his ultimate victory over sin and death).

Tom celebrates his "victory" by singing an Isaac Watts's hymn that begins, "When I can read my title clear / To mansions in the skies" (557). Tom's victory over sin and death in Christ assures him a place in the house of his Father (God) in heaven. Watts's hymn draws on Christ's words in John 14 the night before his crucifixion, the same words that Tom reads from his Bible as he begins his first steamboat journey downriver (229): "Let not your heart be troubled; ye believe in God, believe also in me. In my Father's house are many mansions.... I go to prepare a place for you." ${ }^{2}$ Watts hymn also draws on the Biblical image of the Judgment Day as a time when all will read in God's book whether they have been saved or damned, but Watts conflates this image with the secular image of a title register, a book in which the ownership and transfer of real property are recorded. Watts's compound image suggests that each person will be able to read in God's book whether he has been reserved a place in God's house in heaven. On the Judgment Day, then, Tom's ownership of his place in God's house will be revealed; it will be revealed that he has "clear title."

In singing the hymn, Tom looks forward to the victory over sin and death and his place in God's house that Christ's death has "bought" for him; but in another sense, Tom does not gain true ownership or selfpossession. ${ }^{53} \mathrm{He}$ merely trades a place in one master's house for a place in the house of The Master, a place that he will keep forever because God holds the title to him permanently and will never transfer it to another. It is this message that Tom takes to the weary and oppressed slaves who are his fellow captives - not a message of freedom but of a new and better master, a "compassionate Redeemer and a heavenly home" (559). If Stowe's relation to Tom is like that of God to Tom, then authorship allows Stowe "perfect" ownership and eternal possession of her characters.

But, then again, God's ownership of Tom is not truly perfect except in heaven. God can only own Tom's soul, not his body. In fact, Tom's soul victory only drives Legree to further abuse Tom's body, thus hastening Tom's death. Tom's body remains subject to sale and subject to "use and abuse" by whoever owns his body as property. Only when Tom dies and is reunited with his creator in heaven, leaving his body behind on earth, is he completely saved from being alienable property.

In some respects, God's relationship to Tom represents a far-reaching fantasy of Stowe's authorial power - as God to her work and her characters, her title to them is both perfect and eternal. However, the dichotomy of body and soul also potentially undermines that power and perfect pos- 
session. Even if Stowe is God to Uncle Tom and her book, she only has Godlike possession before she publishes her book; if she absolutely owns Tom's soul in some spiritual sense, she can have, as Grier's decision makes clear, no property rights in that soul. Once she reveals that soul to others clothed in language, once she "publishes her book," Tom's immaterial part becomes public property, which is to say no one's property. As Grier opines in Stowe v. Thomas,

An author may be said to be the creator or inventor, both of the ideas contained in his book, and the combination of words used to represent them. Before publication he has the exclusive possession of his invention. His dominion is perfect. But when he has published his book and given his thoughts, sentiments, knowledge, or discoveries to the world, he can have no longer an exclusive possession of them.... The author's conceptions have become the common property of his readers, who cannot be deprived of the use of them, or their right to communicate them to the world, clothed in their own language. (206)

To retranslate these concepts back into the novel's terms, Tom's earthly body, his material part equivalent to the material "clothing" of Stowe's ideas in language, belongs to Stowe, and only she has a right to make and sell copies of Tom's "body." However, others may appropriate Tom's "soul" (the immaterial thoughts, sentiments, and ideas constituting his character, which Stowe communicated to readers through language) and clothe it in new earthly bodies, even figuratively applying the lash to Tom's body until he is horribly disfigured. With multiple Toms circulating in the market (Stowe's authorized Tom and the disfigured Toms who resemble him), how are readers to know which Tom is the real Tom? How are they supposed to see through to his divinely created "soul" (that is, to Stowe's ideas)? In the world of the literary marketplace, as Grier's opinion recognizes and even encourages, even Tom's "soul" is in danger of being disfigured and corrupted as a result of the proliferation of disfigured Tom bodies.

The novel illuminates not only Stowe's authorial conflict with the market and her only partially successful attempts to make over property relations in the image of the divine maternal author; the novel also illuminates her inevitable participation in market relations as a proprietary author. ${ }^{54}$ I want to return to and complicate the notion of Stowe's position in Stowe v. Thomas as analogous to that of Mrs. Shelby in Uncle Tom's Cabin. Although Mrs. Shelby takes a maternal role with the slaves on her husband's plantation, she is not the woman who gave birth to them or "made" them. Stowe, as an author-mother, gives birth to her literary children and also raises them. In some respects, then, Stowe's role as an author-mother is analogous to that of the many slave mothers she portrays in the novel, including Cassy, who have their children sold away 
from them. However, as the white "mother" of black "children," Stowe, as an author-mother, more closely resembles her white male slave-owning characters, such as Cassy's father and Cassy's "husband"-owners, who are both biological fathers of and owners of some of their slaves. In an 1856 letter, Stowe's childhood friend Georgiana May plays on just this implied relation of Stowe as an author to her characters. May reports that she is in the middle of reading Stowe's second novel, Dred, and she plays on one of the primary slave characters in the novel: "I have made 'Old Tiff's' acquaintance. $H e$ is a verity - will stand up with Uncle Tom and Topsy, pieces of negro property you will guilty of holding after you are dead. Very likely your children may be selling them" (C. Stowe, 269). ${ }^{55}$

As May's remarks make clear, both Stowe's owning and selling of Uncle Tom and her other slave characters are peculiar economic and legal phenomena. Just as slavery was America's peculiar institution and slaves a peculiar form of property, "things" under the law that were also thinking, feeling human beings, copyright ownership is a peculiar form of ownership. Stowe both holds and sells her "negro property," and her children may do the same after her death. As Francis Lieber argued in his 1840 treatise in favor of international copyright, unlike real estate, the primary value of copyright as property does not lie in the thing itself. Instead, "Its value consists chiefly in the right of multiplying the work" (22). Stowe v. Thomas ultimately reveals that Stowe's structural relation to the marketplace is not like Mrs. Shelby's or even like that of a slave trader like Haley. Her "negro property" is not sold downriver once, forever escaping her control unless she buys that property back; instead, her characters, dressed in language and clothed in the paper of copies of her book, can be multiplied and thus sold again and again. This is both the magic and the horror of copyright - Stowe as an author can sell her "children" over and over again (at least until the term of her copyright expires - another limitation on her claims to absolute and eternal possession). In fact, although copyright also gives her the authority not to sell her children, and to prevent others from selling them, her right only has economic value if she sells them and prevents others from selling them without her permission. To be an author under the copyright law is by definition to sell one's literary children in the market, whether an author sells those children once to a publisher by transferring the copyright outright or retains title in order to directly control their repeated sale.

\section{CONCLUSION}

The failure of the English-speaking press to report extensively on Stowe v. Thomas or to comment on its significance was, perhaps, perversely fortunate for Stowe's continuing authorial power and success. Although the press (and particularly the Southern press) sometimes casti- 
gated her for her commercial motivations, and although many reported and commented on Stowe's profits from the record-breaking sales of $U n$ cle Tom's Cabin, Stowe for the most part maintained a public persona of commercial disinterestedness, and she was just as famous for how much money she lost to English sales of the novel (for which she received no royalties) as she was for her American profits. Even her published comments (quoted earlier) on the injustice of the unauthorized English publication of her novel were testimony to her dispossession in the market because of the copyright law rather than to her proprietary triumph. As James Parton, then President of the American Copyright Association, wrote in the opening sentence of an 1867 Atlantic Monthly article in favor of international copyright, "There is an American lady living at Hartford, in Connecticut, whom the United States has permitted to be robbed by foreigners of $\$ 200,000$. Her name is Harriet Beecher Stowe" "International," 430). If slavery had, as Stowe claimed in Uncle Tom's Cabin, robbed slaves of their very selves, copyright proponents in post-Civil War America implicitly aligned Stowe with the slave, rather than the slave owner: she was a woman unjustly robbed of the products of her labor. As slavery as a present reality receded, copyright proponents became more explicit in their invocations of this analogy between the American or the English author disempowered by the lack of Anglo-American copyright and the slave unprotected by the law in antebellum America. ${ }^{56}$ Argued David McGregor Means in the Independent in 1886,

No one can imagine a more sacred right of property than the right which every man has to sell the labor of his hands. But twenty-five years ago this right was not recognized in some portions of our country. Every argument that can be advanced against copyright could have been urged against emancipation. It is true that an author cannot be compelled to write by the lash, as a slave was compelled to work; but if, under pressure of necessity, a foreign author does write, and is unfortunate enough to write anything that the American public cares for, that public can take it from him without recompense - without even the recompense of his daily bread, which the master allowed his slave. (229)

Particularly suggestive is the striking resemblance between this analogy and the then current feminist analogy between the married woman under the law of coverture and the chattel slave.

When Stowe entered the realm of copyright, then, she was both empowered and disempowered. The law offered Stowe both commercial power and the chance to claim status as a divine creative figure. But the law, as Stowe $v$. Thomas reveals, also granted her only limited private property rights, favoring instead the reading public's right of access, and revealed the cracks and fissures between her competing authorial personae. 
She claimed to be a mere passive scribe and domestic producer of material objects, but she also attempted to assert property rights in her immaterial, incorporeal work as an author invested with full Romantic agency. By asserting her claim in Stowe $v$. Thomas, she attempted to push the boundaries of the American law's concept of authorship and the author's property, but this concept of authorship was also inextricably bound up with the economic rights to be enjoyed by the owner of a copyright; and the extension of the author's economic rights potentially diminished readers' opportunities for access and use. Some, like George Ticknor Curtis, maintained that the law failed to recognize the true nature of the author's property in his creations and asked that the law recognize the author's true power. However, such arguments for recognizing the author's power were also attempts to create new power through the agency of the law; and if the law did not grant that power so that the author could exercise the power in the marketplace, the author's supposed power was illusory. When Congress greatly expanded the rights of the author under copyright by passing the International Copyright Act in 1891 (and earlier and on a smaller scale in 1870, when Congress gave copyright owners the ability to reserve and control dramatization and translation of their works), the law shifted the allocation of power between author and reader, no longer finding its primary rationale in serving readers' needs for access, but instead looking to expand and reinforce continually the growing property domain of the author.

In fact, although the author was clearly gendered male in the international copyright debates (e.g., the concern voiced in Congressional documents about the fate of widows and children of deceased authors), the American law before 1891 expected from authors the sort of selfeffacement and selflessness often evinced by Stowe and many of her female contemporaries. If authors were enslaved by readers who took their labors and property from them without compensation, who better to occupy the position of author than a woman, whose claims to her own labor and property might already be tenuous? Even in the context of Stowe $v$. Thomas, Stowe, as a married woman, could only attempt to recover her property with the cooperation and consent of her husband. Under the law of coverture, Calvin Stowe was the single legal subject created by the union of Harriet and Calvin in marriage. Although she registered the copyright to the novel in her own name, the property thus acquired immediately became her husband's. Calvin Stowe signed the publication contract with John P. Jewett, and Calvin Stowe was the primary plaintiff in the suit against Thomas. ${ }^{57}$ Catharine Gallagher argues in Nobody's Story that Charlotte Lennox served as a representative author in $18^{\text {th }}$. century England because both the literary market and marriage dispossessed her of her literary property, and I want to suggest that Stowe was a similarly representative author in 19th-century America. Stowe, like Lennox, served "as a hyperbolic instance of authorial suffering" because 19th-century American authors, like $18^{\text {th }}$-century English authors, were 
in a "feminized' position" in relation to the literary market (196). ${ }^{58}$ Even though the law placed clear limits on the power of the author, those limits did not prevent Stowe and her similarly self-effacing female peers from succeeding commercially on an unprecedented scale. ${ }^{59}$ Indeed, those limits may, paradoxically, have enabled the commercial success of Stowe and her female peers by allowing them to appear both to be powerless and selfeffacing and to exploit fully the circumscribed possibilities of the market.

\section{NOTES}

I thank the following people for their responses to earlier versions of this essay: Jennifer Jordan Baker, Nancy Bentley, Peter Conn, Jeannine DeLombard, Betsy Erkkila, Leigh Edwards, Christopher Looby, Ashley Montague, and Siva Vaidhyanathan. I also thank audiences at the American Studies Association, the Society for the History of Authorship, Reading and Publishing, and the Philobiblon Club for their feedback. This essay would not have been possible without many marvelous libraries and their staffs, including the American Antiquarian Society, the Free Library of Philadelphia, the German Society of Pennsylvania Library, the Historical Society of Pennsylvania, the Library Company of Philadelphia, the Library of Congress, the New York Public Library, the Mid-Atlantic Regional Branch of the National Archives, and Van Pelt Library at the University of Pennsylvania. Research for this essay was funded in part by a Kate B. and Hall J. Peterson Fellowship and a Mellon Post-Dissertation Fellowship at the American Antiquarian Society. Translations of original German materials were produced in collaboration with Clinton Stevens, whose labors were funded by the Honors Research Assistant Program of the Honors College at the University of Oklahoma.

1. Throughout I will be quoting from and citing page numbers from the version of the case collected in the Federal Cases at the end of the century ( 23 Fed. Cas. 201, Case No. 13,514). The case was originally reported by John William Wallace, the reporter for the Third Circuit ( 2 Wall. Jr. 547). The case was also reported in the American Law Register without the arguments of counsel (2 Am. Law Reg. 210). In the American Law Register and in the manuscript, the last sentence begins, "In tropical, but not very precise phraseology ..." See my later detailed discussion of the text of the opinion for other key textual variants. Thomas's translation was not the only unauthorized German translation. Lewis N. Dembitz published a serialized translation in the Beobacther am Ohio, a Louisville, Kentucky, paper. For the circumstances of this publication, see John Weisert. It is not clear whether Stowe never discovered this publication, or whether she discovered it and forced the newspaper to stop because only a single issue of the newspaper (February 14,1853 ) survives.

2. Benjamin Kaplan mentions the case in passing in An Unhurried View of Copyright (1967) as evidence that American justices "clung" to an outmoded view of copyright as "protecting only the very book, the precise concrete expression" (29). In Copyright in Historical Perspective (1968), L. Ray Patterson mentions the holding of the case in the context of a discussion about the "continuing discontent" of jurist and Congress with the copyright law and the subsequent statutory tinkering that resulted (ch. 11). In his more recent coauthored book, The Nature of Copyright (1991), Patterson cites Stowe v. Thomas as typical of narrow constructions of the copyright law by the courts that forced Congress to expand the rights under the copyright statute to be fair to authors; however, argues Patterson, even though such expansions were "nominally to benefit authors, [the benefit] accrued 
primarily to publishers" (Patterson and Lindberg, 77). In a 1987 article on the implications of the copyright law for the production and distribution of books in 19thcentury America, Alice Schreyer calls Grier's holding "undoubtedly extreme," but notes that "the language of nineteenth-century copyright law did prevent piracy better than plagiarism" (128). In a 1991 law-review article tracing the metamorphoses of the concept of "authorship" in the law and the replacement of authorship with a concept of "the work" abstracted and separated from the author, Peter Jaszi quotes Grier's conclusion but does not analyze it, simply noting it as evidence that "a mature concept of the work" emerged later in America than in England. In his 1994 book on the past and future copyright, Paul Goldstein briefly treats Stowe $v$. Thomas only as a way to look forward to questions raised later by new technologies, saying that to ask "whether copyright entitles the author of an Englishlanguage novel to enjoin a publisher from issuing an unauthorized German translation is, at bottom, like asking whether the novelist is also entitled to control the use of novel in motion pictures or television productions based on it" (57). Meredith McGill's discussion of the case in the context of her article on Wheaton $v$. Peters and Robert Cazden's discussion in his book on German publishing in 19thcentury America will be discussed below. It is interesting to note, however, that a scholar of German-language publishing has given more space and prominence to the case than any scholars focusing on English-language publishing (see my later discussion of how the case held little interest for the English-language press in 1853 , but was widely discussed in the German-language press).

3. I have found no reliable documentary source attributing precisely this statement in exactly these words to Stowe. However, she clearly did often figure her authorial labor as subsidiary to God's agency in the composition of the novel. See, for instance, her son's statement in his biography of Stowe that she "repeatedly said . . . 'I could not control the story; it wrote itself,' or 'I the author of 'Uncle Tom's Cabin'? No, indeed. The Lord himself wrote it, and I was but the humblest of instruments in his hand. To Him alone should be given all the praise" (C. Stowe, 156). In any event, clearly in the popular imagination, the statement captured a perceived truth about Stowe as an author.

4. Some claimed that Uncle Tom's Cabin sold millions in the United States by the end of the century. Accurate circulation figures for 19th-century books are almost never available. In her analysis of the sales successes of popular women writers in the $1850 \mathrm{~s}$, Susan Geary relies on numbers derived from an 1858 trade publication, the American Publisher's Circular, and finds that sales figure of 310,000 copies of Uncle Tom's Cabin far outstripped its nearest fictional competitor, Maria Susanna Cummins The Lamplighter, which was credited with sales of 90,000 ("Domestic Novel," 370). Whatever the accuracy of Geary's numbers, they at least have the advantage of representing the perceptions of Stowe's knowledgeable and sophisticated contemporaries in the book trade. Although others cite much higher figures for cumulative sales in subsequent years, the figure of 300,000 is the most relevant here because Stowe filed suit against Thomas about a year after initial book publication.

5. See Susan Geary ("Harriet Beecher Stowe") and Susan Coultrap-McQuin (ch. 4) for Stowe's after-the-fact dispute with her publisher over royalty rates. Whether or not one believes that Jewett really did give Stowe lower than the customary royalty rate, thus depriving her of her fare share of the profits, the aggregate amount of money Stowe received put her in a class by herself.

6 . The law regulating performance and dramatic adaptation rights has its own complex history, which I will not discuss in detail here because Stowe showed little interest in claiming or exploiting such rights. Others profited greatly from performances of dramatic adaptations of Uncle Tom's Cabin, but the law gave Stowe no right to control such adaptations and performances. In 1856, Congress amended the law to give the owner of a copyright in a play the exclusive right to 
control performances of that copyrighted play, but Congress did not amend the law to give the owner of the copyright in a novel the exclusive right to adapt that novel into a play until 1870. See Thomas Gossett (ch. 14) for the descriptions of the many different stage adaptations of Uncle Tom's Cabin. Note, however, that Gossett incorrectly states that the 1856 Copyright Act allowed "a novelist to control or gain financial benefit from a stage production of his fictional work" (260).

7. The author is the legally defined person in copyright law to whom property rights accrue, but the author may, and often does, assign those rights to another, commonly the publisher. Thus, in practical terms, as L. Ray Patterson and Stanley Lindberg argue, expanding the rights of the "author" in copyright law often actually expands the domain of the publisher, not the author (77). However, Stowe did not assign her copyright in Uncle Tom's Cabin, and the question of copyright was, and is, still widely perceived as a question of "author's rights."

8. Eaton Drone's observation was probably not strictly accurate. The copyright may have been the most valuable copyright in a work of imaginative literature, but many nonfiction works (e.g., religious tracts, school textbooks, law books, and various forms of reference books) were far more widely distributed during the 19 th century than even Uncle Tom's Cabin. In the 19th century and today, very few reported copyright cases concern works of fiction or poetry, a fair indicator that these copyrights were not considered and are not considered valuable enough to merit the expense of litigation (although disputes concerning drama and music in the 19th century did and disputes concerning film and music in the 20th century do reach the courts with some frequency).

9. See, for example, James Parton's 1867 Atlantic Monthly article on international copyright, from which I quote later in this essay.

10. The best account of the international copyright controversy and organizing efforts remains that by James J. Barnes. See also Michael Newbury's analysis of the metaphors deployed in these debates.

11. The authorship of the pamphlet is in dispute. George Goodspeed suggests that the pamphlet may have been written by Cornelius Matthews or as a true collaboration between Matthews and Bryant. He claims that the only basis for the attribution to Bryant is the appearance of Bryant's name first in the list of officers at the end of the pamphlet (111-12). William Cullen Bryant III and Thomas G. Voss attribute it to Bryant in their edition of Bryant's letters (246-47). In any event, most readers would probably have assumed that Bryant had some role in the authorship because of the prominent placement of his name and because of his editorializing in the Evening Post in favor of international copyright.

12. E. Bruce Kirkham (E-mail to the author), who has collected copies of all known Stowe correspondence and who is preparing an edition of Stowe's letters, has reported to me that his database of letters includes no correspondence concerning the suit. I have been unable to locate any published comments by Stowe on the suit.

13. Greeley replied, "It is a great shame, a great wrong, a great mischief, that an Author's right to the fruits of his own labor or genius are not recognized by our laws, but it is hard to fix the public attention fully and earnestly on a matter so far removed from the general current of thought and popular interest - especially when the majority superficially presume their personal interest is identified with the wrong side."

14. France's copyright tradition has a very different genealogy, which I will not treat here (see Karla Hesse and Molly Nesbit).

15. Mark Rose's analysis stops short of a full consideration of English Romanticism and its convergence with the copyright law, but as he argues, "In representing the author as a specially gifted person able to produce from the depths of personal experience an organically unified work of art, romanticism provided codified answers to critical legal questions" about the special nature of authorship 
and literary property (Authors, 132). William Wordsworth called on the Romantic ideology of original genius in his petitions to the British Parliament in the early 19th century, asking Parliament to extend the term of copyright protection in England (Woodmansee and Jaszi, 4-5). For the convergence of "authorship" in the law with the ideology of Romanticism and the consequences for American copyright jurisprudence in the 19th and 20th centuries, see Peter Jaszi (esp. 466-71). Taking a slightly different route, Catharine Gallagher also emphasizes the birth of originality and immateriality as characteristics of literary property in the 18th century. Noting the detachment of author from circulated book enabled by printing, Gallagher argues,

The appearance of the multiplied, perfected text magnified [the author's] lack of dependence on any particular material object. The more standardized and impersonal the medium became, the more sovereign the creating mind appeared. ... the reproduction and sale of the identical text in numerous copies provided proof of the ideas' transcendent nonmateriality, their escape from the physical accidents of place and time, and therefore their substantive likeness to the immaterial and immortal mind they represented. (63)

16. Meredith McGill, using Michael Warner's terminology from Letters of the Republic (1992), identifies the American law's approach to the regulation of print as "republican." Grantland Rice, analyzing some of the same materials, labels this legal approach more broadly "utilitarian," noting the persistence of a utilitarian approach in England (76-78).

17. Indeed, the Senate report description of how books are made sounds very much like a 1753 German dictionary definition of "Book" quoted by Woodmansee as an example of the understanding the Romantics sought to supersede:

Many people work on this ware [a book] before it is complete and becomes an actual book in this sense. The scholar and the writer, the papermaker, the type founder, the typesetter and the printer, the proofreader, the publisher, the book binder, sometimes even the gilder and the brass-worker, etc. Thus many mouths are fed by this branch of manufacture. (425)

18. For a recent treatment of Carey's theories, see Andrew Dawson (although Dawson does not include Carey's writings on copyright in his analysis). See also A. D. H. Kaplan and George Winston Smith. Smith focuses particularly on Carey's analysis of slavery and the slave trade in the context of sectional conflict, noting his position, not for slavery but not for abolition, that made him at home with neither abolitionists nor slavery apologists. He claims that Carey's treatise Slave Trade, Domestic and Foreign: Why It Exists, and How It May be Extinguished (1853) was "in a sense a response" to Stowe's novel, "the greatest of all propaganda novels against slavery" (35).

19. Copyright proponents continued to claim the centrality of author's rights, but they compromised with manufacturing interests by supporting legislation that allowed non-citizen/resident authors to secure copyright in the United States only if their works were published in the United States within a limited period of time after foreign publication, and only if all copies sold in the United States were manufactured entirely in the United States.

20. I am quoting page references from an edition published in 1868 , which includes a lengthy preface that I will take note of later. However, the main text of the 1853 edition remains intact in the 1868 edition.

21. Forrest Wilson, the only Stowe biographer to make more than passing note of the Stowe $v$. Thomas decision, garbles the facts in a number of ways. He asserts 
that the case waited two years for a decision on appeal (331), when actually Stowe filed suit on March 11, 1853 (two and a half months after Thomas began serial publication on January 1,1853 ), and obtained a preliminary injunction against Thomas on March 22, 1853, several days after Thomas completed serial publication but before he was able to publish the complete translation in book format. Strodtmann's translator's afterward to the Thomas edition is dated March 16, 1853, and does not mention Stowe's suit - indeed, Strodtmann writes of his plans to translate Stowe's "next work." Apparently, Thomas and Strodtmann did not learn of the suit for several days and were blithely moving ahead with the book edition. The case was not heard until October 27-28, 1853, when the court was in session, but Thomas had already been enjoined from further publication, so Stowe suffered no additional harm in the interim. Justice Grier rendered his decision on December 24, 1853. Thomas subsequently issued a complete translation in book form, which went through several editions (Cazden, $370 \mathrm{n}$ ). Wilson was most likely confused because the Stowe $v$. Thomas decision was rendered by a federal circuit court, which is normally a court of appeals. However, under the copyright statute in effect in 1853 , the circuit courts had original jurisdiction over copyright cases. My reconstruction of the factual scenario comes from the manuscript case file for Stowe v. Thomas in the Mid-Atlantic Branch of the National Archives, from my examination of the 1853 issues of Die Freie Presse, and from reports in Philadelphia daily newspapers, particularly the Cummings' Evening Bulletin, which gave extensive routine coverage of the federal courts sitting in Philadelphia.

22. See chapter 4 of Bruce Kirkham's Building of Uncle Tom's Cabin for a summary of the various accounts of Stowe's composition of the novel and their sources. On the process of writing the novel as childbirth, see the most complete account of the "communion table" vision in her preface to the $\mathbf{1 8 7 9}$ edition of the novel, which makes Stowe a close analog to the unwilling Mary of the annunciation, impregnated by an all powerful God at the moment of inspiration, and which figures her subsequent creative labor as the involuntary labor of childbirth. See also her comments reported by J. C. Derby that "[c]reating a story is like bearing a child, and it leaves me in as weak and helpless a state as when my baby was born" (521). For domestic scenes of production, see, for example, James Parton (Daughters, 77), and untitled account in the Woman's Journal (When Mrs. Stowe), and E. P. Parker's 1868 biographical sketch (312).

23. Thanks to Siva Vaidhyanathan for drawing my attention to this reference.

24. This was precisely the issue resolved by Wheaton v. Peters. Although the plaintiff asked the court to find that an abridgment of the U.S. Supreme Court reports infringed the copyright in the original reports, the court did not rule on the question of abridgment as infringement because it held that the plaintiff had not fulfilled all of the necessary registration requirements and therefore had no copyright that could be infringed.

25. Michael Newbury describes the court's rejection of Stowe's claim as being of a piece with the failure of efforts on behalf of international copyright, saying, "Once again. ... the rights of literary ownership and the sense of the text as an ownable commodity were drastically circumscribed when they might well equally well have been strengthened by the courts" (183). However, as my discussion will make clear, the court did recognize Stowe's text as a material "ownable commodity" like other ownable commodities. If the court had recognized its immaterial nature, Stowe's claim would have succeeded.

26. Even after devoting this much space in its widely circulated weekly edition to the case, the Tribune, as did all other papers I have reviewed, failed to report on the final outcome of the case. This omission is particularly striking concerning the extended point-by-point refutation of Henry Carey's anti-copyright argument that the Tribune published on Dec.ember 31, 1853 (on Carey and Carey's critique of Stowe v. Thomas, see below).

27. See Mark Rose (Authors, 78-82), L. Ray Patterson (Copyright, 168-72), 
and Benjamin Kaplan (12-15) for accounts of the circumstances surrounding this case.

28. My use of the masculine pronouns reflects Grier's usage in the text of his opinion. For instance, in the Stowe $v$. Thomas decision, all generalized discussions of the nature of copyright use the masculine pronoun to refer to the author. Only in the last paragraph when he discusses Uncle Tom and Topsy does Grier switch to the feminine pronoun to discuss Stowe as a particular author. Although Grier and others probably would have claimed that the masculine pronoun should be construed as inclusive, it is just as clear that arguments concerning the nature of authorship reflect an assumption that "the author" is masculine.

29. The word copyright preceded the 1710 enactment of the Statute of Anne, the first English copyright statute. An author sold to a publisher his copy or manuscript, and a publisher then registered that copy in the Stationers Register, thereby putting other publishers on notice of his sole right to publish the copy (that is, he registered his copy right). As L. Ray Patterson and Stanley W. Lindberg note, the assumption that the "copy" in "copyright" is a verb (the right to copy) rather than a noun (the right in a copy) is a modern misstatement of history. Although Grier's use of the word copy to indicate a thing that has been copied comes close to this modern misperception, he makes clear that a right in a copy gives its owner the right to multiply the copy, not to prevent others from copying it.

In modern copyright jurisprudence, the principle that Grier is articulating here is referred to as the idea-expression dichotomy. However, in 1853, this precise terminology was not in use. Legal writers sometimes refer to authors ideas as not being protected by the law, but as frequently or more frequently use the word conceptions. The word expression (as opposed to language or words) to denominate what the law does protect does not come into common use until the 20th century. Rather than use anachronistic language, which carries with it, potentially, an anachronistic understanding of the issues, I am working with the 19th-century terms. In any event, even modern scholars agree that the distinction between idea and expression (with expression understood as being more than the language that appears on the page) is not as clear as it first seems - when does plot, for instance, become expression (and protected) rather than (unprotected) idea?

30. According to the Biographical Encyclopedia of Pennsylvania of the Nineteenth Century, Samuel H. Perkins was admitted to the bar in July 1851 after studying law in his father Samuel C. Perkins's office. Samuel H. also earned an LL.B. from the University of Pennsylvania in 1852 (51). Forrest Wilson erroneously claims that Stowe's family lawyer from Hartford, T. C. Perkins, handled the case (331). Unfortunately, no legal correspondence from 1853 survives in the papers that Samuel H. Perkins deposited with the Historical Society of Pennsylvania, but the Philadelphia Perkinses were clearly the lawyers representing Stowe.

31. The Perkinses are quoting from the definition of author from Noah Webster's Dictionary. However, it should be noted that Webster's definitions of key copyright terms are not neutral and descriptive. Webster engaged in extensive personal lobbying of state legislatures and Congress before the passage of the first federal copyright statute in 1790, and testified before Congress in favor of the extension of the copyright term in 1830 . His "blue-back" spelling books sold tens of millions of copies, so his interest in expanding the author's property rights under copyright were even greater than those of Stowe. For the extraordinary sales of Webster's spellers and his efforts on behalf of copyright term extension, see E. Jennifer Monaghan.

32. Grantland Rice seemingly confuses George Ticknor Curtis with his publisher cousin, George William Curtis, and characterizes his treatise as a "defense of utilitarian rights" (86). Although Curtis does concede some of the tenets of the utilitarian position, overall, he argues for an expansion of the author's individual 
rights under copyright and for the fundamental immateriality of the author's work as a basis for the expansion of those rights.

33. "We have confessedly taken not a part, but the whole. We concede and we boast that we have taken every syllable, comma, and i-dot of the original" (205).

34. On German support of abolitionism, see Bruce Levine.

35. As documented by Stowe's affidavit filed in Stowe v. Thomas, Calvin Stowe even assisted von Hutten with the translation:

That some time in the year 1852 she employed at much expense Hugo Rudolph Hutten a competent German scholar of ability and skill and critical knowledge of the German and English languages to translate said Book. That said German scholar was assisted in his labors by the above Complainant Calvin E. Stowe whose wife this Deponent is. That by these individuals at the expense and charges of the Deponent said Book has been fully and completely accurately and carefully translated and copied into the German language; and the same has been printed and published in German by this deponent and all the provisions and requisition of the several Acts of Congress respecting Copyrights have been complied with in respect to this edition of said Book. (Stowe $v$. Thomas, Manuscript, affidavit, 5)

Joan Hedrick documents Calvin Stowe's book-buying trips to Germany on behalf of academic libraries (99-101). The affidavit of John P. Jewett, Stowe's publisher, adds more details concerning publication of the authorized translation and documentation of the copyright. See also Jewett's advertisements in the February 18, 1853, Liberator advertising a February 15 publication date, and advertisements of two German bookstores (Schäfer \& Koradi and Weis \& Wick) in the March 2, 1853, Philadelphier Demokrat advertising the authorized translation as available. The authorized translation was clearly available on March 2, if not February 15, so, for a period of several weeks, Stowe's authorized translation competed directly with the continuing serialization in Die Freie Presse.

36. The complaint and Stowe's and Jewett's affidavits also make note of the existence of this translation, although they provide no details. I have examined a copy of what is apparently the "authorized" Everett Welsh translation, and, interestingly, it contains no copyright notice whatsoever (Stowe, Caban).

37. As her attorneys noted at the beginning of their arguments, the question of translation had been made the subject of legislation in continental Europe, but the question was actually much more pressing in America, where the copyright statute made no special provisions:

The question is more important in America than elsewhere, owing to the originally mixed character of our people, and to the constant emigration of foreigners to our country, most of whom become our citizens long before they can read our language. This influx from the continent of Europe is greatly increasing. It will go far to change the nature of our population. There is no doubt that the question is of deeper importance in this country than it ever has been in this or any other country, at any time before. (201)

38. In a formulaic brief report copied almost verbatim to several other Philadelphia papers, the Cummings' Evening Bulletin reported the outcome of Stowe v. Thomas in a few sentences on Saturday, December 24,1853 , the day that Grier read the opinion in court. The brief did little more than note that the decision was "the first... either in Europe or America" on the precise question and praise the "learning" demonstrated by the judge and attorneys. See also brief 
notices in the Daily News of December 26 ("Important Decision"), the North American and United States Gazette of December 26 ("Uncle Tom's Cabin"), the Sunday Dispatch of December 25 ("Uncle Tom in Court"), and the Pennsylvania Freeman of December 29 ("Important Decision"). Several papers also printed the decision in its entirety, but with only a brief introduction noting the case's novelty; and the New York Times copied a case report from the Pennsylvanian ("Interesting Decision") on December 27, but, again, with only a single introductory sentence. Because of the extremely low survival rate of German newspapers (I was able to locate only a handful of German-language newspapers from 1853, even though hundreds are known to have been published at that time), my claim about the prominence given to the case in such venues is necessarily speculative. However, the prominence and vehemence of the New-Yorker Staats-Zeitung piece (April 6), the reprinting of the piece in the Atlantische Studien (Reventlow and Becker) and the separate piece in the Atlantis (Letter) in response to the Staats-Zeitung piece are strong evidence of a much stronger interest and concern than shown by English-language press. The rival German-language newspaper in Philadelphia, the Philadelphier Demokrat, did not cover the case, but this omission is not surprising considering the paper's opposite political stance to Freie Presse (FonesWolf and Shore, 64-65) and thus was likely unwilling to give publicity, good or bad, to its political and commercial rival.

39. Robert Cazden's work has been an invaluable guide into my research into the German-language press's response to this case. He identifies the authors of the article discussed below, identified only as " $R$ " and " $B$ " in their bylines, as Otto Reventlow and August Becker ( $370 \mathrm{n})$. Like Cazden, I cite to the Atlantische Studien appearance of the article (Reventlow and Becker), even though I have determined that the Atlantische Studien appearance is a reprint of two separate articles originally published in the New-Yorker Staats-Zeitung (Reventlow, "Ist Uebersetzung Nachdruck?" and Becker, "Mrs. Harriet Beecher Stowe"). The reprinted appearance is far more legible, and the appearance of the articles on twelve magazine pages rather than two newspaper pages makes citation to specific passages more precise. Of course, the most interesting press account would be that published in Thomas's own paper. However, Thomas did not report Stowe's initial filing of the case or the court's issuing of a preliminary injunction. He mentioned the court hearing only briefly in an untitled paragraph in the October 28 paper, and then on December 26, just after Grier issued his opinion, he offered some "short remarks" on the opinion and promised to comment on the case in more detail later. I have examined what is apparently the most complete run of Die Freie Presse at the German Society of Pennsylvania, and I have found no subsequent report. However, the Monday January 2, 1854, issue of the newspaper, a likely date on which the report might have been published, is missing from the German Society run of the paper. The January 7, 1854, Cincinnati Volks-Blatt reprinted a German translation of Grier's opinion, crediting it to the Freie Presse, so, at the very least, Thomas must have run a translation of the opinion in that missing January 2 nd issue.

40. August Becker concludes his piece with a criticism of Stowe's failure to settle: "She seems to have thought only of making money, otherwise she wouldn't have insisted on suppressing the Strodtmann translation. This is made even more obvious by the fact that an arrangement with $\mathrm{Mr}$. Thomas could have easily been made" (214). Most of Becker's article actually argues against the existence of a German-language market for Stowe's novel because of the weak national/cultural identity of the immigrant community, their debased tastes in literature, and the lateness of publication of both translations. As Cazden notes, however, the fact that after winning the suit, Thomas printed several editions of the Strodtmann translation, the last in 1874 , strongly suggests that there was a market for the book $(370 \mathrm{n})$. 
41. Although the manuscript of the opinion clearly includes these sentences, the Third Circuit reporter John William Wallace, either inadvertently or intentionally, omitted these sentences in his published version of the opinion, and Grier's reasoning nevertheless remains clear and coherent. The two sentences omitted from Wallace's reports but included in the American Law Register are "Uncle Tom and Topsy are as much publici juris as Don Quixote and Sancho Panza" and "They are no longer her own - those who have purchased her book, may clothe them in English doggerel, in German or Chinese prose. Her absolute dominion and property in the creations of her genius and imagination have been voluntarily relinquished."

42. In late 1850, Grier asked President Fillmore for a general order authorizing the deployment of federal troops to preserve order, and he used his published charges to juries in Fugitive Slave Law cases to pontificate on the importance of enforcement of the law to the preservation of the union. Not surprisingly, such behavior did not endear him to abolitionists, particularly those who counseled resistance to the Fugitive Slave Law. See, for instance, William Lloyd Garrison's late 1852 editorial in the Liberator concerning the so-called Wilkes-Barre Slave Case prosecuted against Northern white men who assisted a fugitive ("Charge"), and another editorial protest in the Liberator against Grier's role in another Fugitive Slave Law case published shortly before Grier's participation in Stowe v. Thomas ("Judge Grier"). Later, in his capacity as a Supreme Court justice, Grier was in the majority on the infamous Dred Scott decision, which denied escaped slave Dred Scott status as a citizen and thus the standing to sue for his freedom in federal court. Grier's career is much less studied than that of most of his fellow members of the Supreme Court under Roger Taney, most likely because few of his papers survive. For brief accounts of his career, see Carl Swisher (572-82), and Frank Otto Gatell. Under the Circuit Court Act of 1802, each federal circuit was presided over by a Supreme Court justice, who rode the circuit from venue to venue, sitting as part of a two-judge panel, with the second judge being the local federal district court judge (Carp and Stidham, 16-17). The circuit panel for Stowe v. Thomas consisted of Grier and Eastern District of Pennsylvania's judge John Kintzing Kane, who was equally unbeloved by abolitionists. Grier's only surviving papers are a few letters to Kane concerning fugitive slave cases that are part of Kane's papers, on deposit at the American Philosophical Society. There are no letters concerning Stowe v. Thomas, although Kane's notes on the attorneys' arguments do survive. They contain no information not replicated in the published reports of those arguments.

43. On the Christiana Riots case, see Paul Finkelman (251-55). Coverage of the case ran in the November and December 1851 National Era. Remarkably, I have found no comment on this striking conjunction in the Philadelphia press's 1853 coverage of Stowe $v$. Thomas, even though Grier's Fugitive Slave Law activities were heavily reported, nor has this conjunction been noticed in any subsequent commentary on the case. See my earlier remarks hypothesizing why this case was largely ignored in 1853.

44. In his Equity Jurisprudence, Joseph Story explains the dilemma faced by judges who, under Anglo-American common law practice, did not grant injunctions under the copyright law to owners of copyrights in obscene works:

It is true, that an objection has been taken to this course of proceeding, that by refusing to interfere in such cases to suppress the publication, a Court of Equity virtually promotes the circulation of offensive and mischievous books. But the objection vanishes, when it is considered, that the Court does not affect to act as a censor morum, or to punish or restrain injuries to society generally. It simply withholds its aid from those, who, upon their own showing, have no title to protection, 
and to assert a property in things, which the law will not, upon motives of the highest concern, permit to be deemed capable of founding a just title or property. (213)

45. The report reads, in part,

Those who desire to see the play of "Uncle Tom's Cabin," now performed nightly at our Theatre, should attend to it at once, or they may be too late - as a report was current last week that an application would be made to Judge Grier of the United States Court (in session in this city,) for an injunction to stop it, on the following among other grounds:

First, it is calculated to bring into disrepute the institution of slavery, and the various acts of congress passed to sustain it, by showing that the very best Christians are liable (when slaves) to be sold in the shambles, religion and all, and whipped to death for adhering to their faith. Second: It is calculated to increase the number of abolitionist "fanatics," and put "kinks" in people's head - thus disqualifying them as jurors in Judge Grier's Court, and directly interfering with the administration of justice according to the law. ... Fifth: Its whole tendency is to encourage slaves to run away from their masters contrary to Scripture and the Fugitive Slave Law - and to incite men to a breach of the peace and to a resistance of the laws of their country; thus encouraging "treason," and striking a deadly blow at the "integrity of the Union."

As a federal circuit justice, Grier would have traveled throughout his circuit territory, which included Pittsburgh as well as Philadelphia, on a regular schedule. Despite modern skepticism that the stage versions of Uncle Tom's Cabin were genuinely abolitionist, as Eric Lott demonstrates (and as this news report confirms) contemporary critics clearly believed that the Tom shows did promote abolitionist sentiment (Lott, ch. 8).

46. As Mark Rose notes in Authors and Owners, pro-copyright forces in the 18th-century British copyright debates used the copyright paternity trope to justify the creation of copyright, arguing that a man has the same right in the children of his brain (his literary creations) as he has in his children, raising the uncomfortable specter of father's freely selling their children in the marketplace (3839). For a detailed theoretical discussion of the copyright paternity trope in the 18th century in England, see also Richard Swartz. Stowe v. Thomas thus does not inaugurate an entirely new copyright trope, but considering Stowe's authorial persona and the values promulgated by her texts, the shock value of the image is certainly more striking. For a suggestive discussion of the implications of the metaphor for the modern law governing reproductive technology, see Rose, "Authors and Mothers."

47. See, for examples, Elizabeth Ammons, Jane Tompkins, and Gillian Brown. But see also Ann Douglas and Lori Merish's contention that Stowe's sentimentality is always deeply complicit in commodity capitalism.

48. I use this phrase in the sense that Richard Brodhead defines it in Cultures of Letters: "A work of writing comes to its particular form of existence in interaction with the network of relations that surround it: in any actual instance, writing orients itself in or against some understanding of what writing is, does, and is good for that is culturally composed and derived" (8).

49. As Susan Belasco Smith notes, this original subtitle "tends to focus our attention on one central character," a focus more appropriate to Stowe's apparently more limited original design of a much shorter work focusing exclusively on Tom, while the published subtitle, "Life Among the Lowly," is more suited to the sprawl- 
ing, multicharacter work she actually produced (73-74). As an index to Stowe's concerns and state of mind as she began writing the novel, however, the original subtitle is still illuminating. Smith's claim that "Stowe sold the copyright of the novel to John P. Jewitt [sic] before the serial had complete its run" (73) is incorrect. Stowe entered into a publishing contract with Jewett before the end of serialization, but she did not transfer the copyright to him.

50. For Stowe's indebtedness to abolition tracts and slave narratives, see Joan Hedrick (ch. 18), Robert Stepto, and E. Bruce Kirkham (76-103). See also Eric Sundquist, who focuses on her divergence from the slave narrative tradition (1617). Stepto accurately characterizes her tone in her correspondence with Frederick Douglass seeking firsthand information from the slave perspective of plantation conditions as showing "a remarkable admixture of civility and imperiousness" (137). Stowe's apparent attempt to appropriate Harriet Jacobs's story for the Key to Uncle Tom's Cabin (1853) (documented in Yellin's edition of Incidents [Jacobs, 234-35]) after the publication of the novel evidences a similar proprietary attitude toward the life experiences of former slaves, but as these events happened well after Stowe's composition of the novel, their relevance to Stowe's composition of the novel are limited. Stowe's Key may seem like a general acknowledgment of her indebtedness to slave narratives, but, as Kirkham makes clear, the Key "is not a compilation of the source material Harriet had on hand when she wrote the novel. The greater part of this material was collected after Uncle Tom was published. She brought it together, not to indicate to the doubtful reader that she had been working from pre-assembled facts and drawing on documentary evidence, but rather to corroborate with data from other sources the authenticity of the scenes she had depicted" (80). For Stowe's indebtedness to blackface minstrelsy, see Saidiya Hartman (26-29) and Eric Lott (33, 222).

51. On the importance of the mixed-genre nature of National Era and its mixed-gender audience to Stowe's literary strategies, see Sarah Robbins and Susan Belasco Smith. See also David Grant for the importance of the Era's free-soil politics to a proper reading of the political valence of Stowe's appeals to and rehabilitation of emotional engagement in her novel.

52. When Stowe puts the verses into Tom's mouth, she omits the clause beginning "ye believe ..."

53. Walter Benn Michaels reads the hymn as evidence of Tom's inability to own property and himself:

$[\mathrm{H}]$ is sense of heaven as a "home" to which he has clear title is barely metaphoric. Slaves, of course, were forbidden to own property, but Stowe thought of them as, by definition, victims of theft. Slavery, "appropriating one set of human beings to the use and improvement of another" (2: 21), robbed a man of himself, and so freedom involved above all the restitution of property. Only in death did the slave's title to himself become "sure"; only in death did Uncle Tom's cabin actually become his. (102)

Michaels misses the question of divine ownership. Tom can't own himself, but God can own his soul.

54. My point here is not to concede to the accuracy of Grier's or the German press's conservative critiques of Stowe's interests in the suit, nor is it to single out Stowe as an author with baser commercial motives than others. I believe that Stowe's novel accomplished significant cultural work, reforming readers' attitudes toward slavery and laying important groundwork for abolition, and I do not believe that she used the abolitionist cause only or primarily to sell her book. However, the copyright law protects economic and property interests, and any proprietary author is, by definition, complicit in market relations.

55. For the record, the copyright in Uncle Tom's Cabin expired in 1895, a year 
before Stowe's death, so it was not part of her estate (the first 28-year term ended in 1879 , and the copyright was duly renewed for a second 14-year term).

56. Not surprisingly, Henry Carey took the opposite approach in his introduction added to an 1868 reprinting of Letters on International Copyright, which he reprinted as a response to Parton's Atlantic Monthly article. He accused Stowe of setting her own economic interests above those of freed slaves who needed cheap books in order to acquire and maintain literacy, and he expressed outrage at her continuing royalties for Uncle Tom's Cabin and her advocacy of international copyright while the widows of Union soldiers (who fought in a war she "caused") could not get government pensions (6-7). Overall, however, as the press became more and more sympathetic to the international copyright cause after the War, the press portrayed Stowe primarily as a victim of the copyright law rather than someone who used the law to victimize others.

57. For a general discussion of 19th-century marital property laws and a detailed discussion of the laws of New York State, see Norma Basch. For an excellent analysis of the related question of a married woman's ability to control her own wages received in return for labor, see Amy Dru Stanley. Susan CoultrapMcQuin notes that the law required Calvin Stowe to sign the publishing contract. The observation concerning Calvin Stowe's status as primary plaintiff is mine and is based on archival research. Although the opinion identifies the plaintiff only as "Stowe," the manuscript complaint and supporting affidavits identify Calvin Stowe as primary plaintiff.

58. The parallel between Lennox and Stowe is not exact because of the differing publishing practices of their times, but the parallel is still suggestive. In 18thcentury England, authors were the persons granted copyright by the law, but they had to alienate that property immediately in order to publish at all - that is, they transferred their copyrights to publishers for a relatively small one-time payment, unless they had the financial resources to self-publish. In contrast, Stowe maintained ownership of her copyright and was paid a royalty, so her dispossession came through unauthorized British reprinting and through Stowe v. Thomas.

59. And the limits of the law did not prevent Stowe from forging ahead with her efforts to exploit the non-English-speaking market - even without legal recognition of her right to control exclusively translation of her works for sale in America, Stowe published a German translation of her second antislavery novel, Dred, a Tale of the Great Dismal Swamp, in 1856, again registering the copyright in her own name and this time not publicizing the name of her translator.

\section{WORKS CITED}

Ammons, Elizabeth. "Heroines in Uncle Tom's Cabin." American Literature 49 (1977): 161-79.

Barnes, James J. Authors, Publishers, and Politicians: The Quest for an AngloAmerican Copyright Agreement 1815-1854. Columbus: Ohio State University Press, 1974.

Basch, Norma. In the Eyes of the Law: Women, Marriage and Property in Nineteenth-Century New York. Ithaca: Cornell University Press, 1982.

[Becker, August]. "Mrs. Harriet Beecher Stowe und 'Onkel Tom's Hütte.' Ein Beitrag zur Christilichen Moral." New-Yorker Staats-Zeitung, April 6, 1853, $1-2$.

The Biographical Encyclopedia of Pennsylvania of the Nineteenth Century. Philadelphia: Galaxy, 1874. 
Brodhead, Richard. Cultures of Letters: Scenes of Reading and Writing in Nineteenth-Century America. Chicago: Chicago University Press, 1993.

Brown, Gillian. Domestic Individualism: Imagining Self in Nineteenth Century America. Berkeley: University of California Press, 1992.

[Bryant, William Cullen]. An Address to the People of the United States in Behalf of the American Copyright Club, Adopted at New-York, October 18, 1843. New York: American Copyright Club, 1843.

Bryant, William Cullen. The Letters of William Cullen Bryant, 1836-1849. Ed. William Cullen Bryant II and Thomas G. Voss. 5 vols. Vol. 2. New York: Fordham University Press, 1977.

Carp, Robert A., and Ronald Stidham. The Federal Courts. 3rd ed. Washington, D.C.: CQ, 1998.

Carey, H[enry] C. Letters on International Copyright. $2^{\text {nd }}$ ed. New York: Hurd and Houghton, 1868.

Cazden, Robert E. A Social History of the German Book Trade in America to the Civil War. Columbia, S.C.: Camden House, 1984.

“A Copy-Right Treaty.” Public Ledger (Philadelphia), December 27, 1853, [2].

Coultrap-McQuin, Susan. Doing Literary Business: American Women Writers in the Nineteenth Century. Chapel Hill: University of North Carolina Press, 1990.

“Courts.... The case of Harriet Beecher Stowe." Cummings' Evening Bulletin (Philadelphia), December 24, 1853, [6].

Curtis, George Ticknor. A Treatise on the Law of Copyright in Books, Dramatic and Musical Compositions, Letters and Other Manuscripts, Engravings and Sculpture, as Enacted and Administered in England and America; with some Notices of the History of Literary Property. Boston: Charles C. Little and James Brown, 1847.

Dawson, Andrew. "Reassessing Henry Carey (1793-1879): The Problem of Writing Political Economy in Nineteenth-Century America." Journal of American Studies 34 (2000): 465-85.

Derby, J. C. Fifty Years Among Authors, Books and Publishers. New York: G. W. Carleton, 1884.

Douglas, Ann. The Feminization of American Culture. New York: Knopf, 1977.

Drone, Eaton. A Treatise on the Law of Property in Intellectual Productions in Great Britain and the United States. Boston: Little, Brown, 1879.

Fields, Annie, ed. Life and Letters of Harriet Beecher Stowe. Boston: Houghton, Mifflin, 1897.

Finkelman, Paul. An Imperfect Union: Slavery, Federalism, and Comity. Chapel Hill: University of North Carolina Press, 1981.

Fones-Wolf, Ken, and Elliott Shore. "The German Press and Working-Class Politics in Gilded-Age Philadelphia." The German-American Radical Press: The Shaping of a Left Political Culture, 1850-1940. Ed. Elliott Shore, Ken FonesWolf, and James P. Danky. Urbana: University of Illinois Press, 1992: 63-77.

"From the Pittsburgh Despatch: Judge Grier and Uncle Tom." Pennsylvania Freeman (Philadelphia), December 15, 1853, [1].

Gallagher, Catherine. Nobody's Story: The Vanishing Acts of Women Writers in the Marketplace, 1670-1820. Berkeley: University of California Press, 1994.

[Garrison, William Lloyd]. "Charge of Judge Grier." Liberator, November 19, $1852,2$.

- "Judge Grier's Decision." Liberator, October 21, 1853, 166.

Gatell, Frank Otto. "Robert C. Grier." The Justices of the United States Supreme Court, Their Lives and Major Opinions. Ed. Leon Friedman and Fred L. Israel. Vol. 2. New York: Chelsea House, 1997: 434-45.

Geary, Susan. "The Domestic Novel as a Commercial Commodity: Making a Best Seller in the 1850s." Papers of the Bibliographical Society of America 70 (1976): $365-93$. 
"Harriet Beecher Stowe, John P. Jewett, and Author-Publisher Relations in 1853." Studies in the American Renaissance, 1977: 345-67.

Goldstein, Paul. Copyright's Highway: From Gutenberg to the Celestial Jukebox. New York: Hill and Wang, 1994.

Goodspeed, George T. "The Home Library." Publications of the American Bibliographical Society 42 (2nd Quarter, 1948): 110-18.

Gossett, Thomas F. Uncle Tom's Cabin and American Culture. Dallas: Southern Methodist University Press, 1985.

Grant, David. "Uncle Tom's Cabin and the Triumph of Republican Rhetoric." New England Quarterly 71 (1998): 429-48.

Hartman, Saidiya. Scenes of Subjection: Terror, Slavery, and Self-Making in Nineteenth-Century America. New York: Oxford University Press, 1997.

Hedrick, Joan. Harriet Beecher Stowe: A Life. New York: Oxford University Press, 1994.

Hesse, Carla. "Enlightenment Epistemology and the Laws of Authorship in Revolutionary France, 1777-1793." Representations 30 (1990): 109-37.

"Important Decision." Daily News (Philadelphia), December 26, 1853, [1].

"Important Decision on Uncle Tom's Cabin." Pennsylvania Freeman (Philadelphia), December 29, 1853, [2].

"Interesting Decision: Uncle Tom's Cabin in German and in Court." Pennsylvanian (Philadelphia), December 26, 1853, n.p.

“Interesting Decision: Uncle Tom's Cabin in German and in Court. Reported for the Pennsylvanian." New York Times, December 27, 1853, 8.

Jacobs, Harriet. Incidents in the Life of a Slave Girl. Ed. Jean Fagan Yellin. Cambridge: Harvard University Press, 1986.

Jaszi, Peter. "Towards a Theory of Copyright: The Metamorphoses of 'Authorship'." Duke Law Journal, 1991: 455-99.

John P. Jewett \& Co. "German Uncle Tom" (advertisement). Liberator, February $18,1853,27$.

Kaplan, A. D. H. Henry Charles Carey: A Study in Economic Thought. Baltimore: Johns Hopkins University Press, 1931.

Kaplan, Benjamin. An Unhurried View of Copyright. New York: Columbia University Press, 1968.

Kirkham, E. Bruce. The Building of Uncle Tom's Cabin. Knoxville: University of Tennessee Press, 1977.

- E-mail to the author. September 1997.

[Letter from New York Correspondent dated April 23, 1853]. Atlantis 1, no. 10 (1853): 157-64.

Levine, Bruce Carlan. "Free Soil, Free Labor, Freimänner: German Chicago in the Civil War Era." German Workers in Industrial Chicago, 1850-1910: A Comparative Perspective. Ed. Hartmut Keil and John B. Jentz. DeKalb: Northern Illinois University Press, 1983: 163-82.

Lieber, Francis. On International Copyright, in a Letter to the Hon William C. Preston, Senator of the United States. New York: Wiley and Putnam, 1840.

Lott, Eric. Love and Theft: Blackface Minstrelsy and the American Working Class. New York: Oxford University Press, 1993.

McGill, Meredith L. "The Matter of the Text: Commerce, Print Culture, and the Authority of the State in American Copyright Law." American Literary History 9 (1997): 21-59.

Means, David McGregor. "The Nature of Copyright." Independent, February 25, $1886,228-29$.

Merish, Lori. "Sentimental Consumption: Harriet Beecher Stowe and the Aesthetics of Middle-Class Ownership." American Literary History 8 (1996): 1-33.

Michaels, Walter Benn. The Gold Standard and the Logic of Naturalism. Berkeley: University California Press, 1987. 
Monaghan, E. Jennifer. A Common Heritage: Noah Webster's Blue-Back Speller. Hamden, Conn.: Archon, 1983.

Nadel, Stanley. "The Forty-Eighters and the Politics of Class in New York City." The German Forty-Eighters in the United States. Ed. Charlotte L. Brancaforte. New York: Peter Lang, 1989: 51-66.

Nesbit, Molly. "What Was an Author?" Authorship: From Plato to the Postmodern, a Reader. Ed. Sean Burke. Edinburgh: Edinburgh University Press, 1995: 247-62.

Newbury, Michael. Figuring Authorship in Antebellum America. Stanford: Stanford University Press, 1997.

Parker, E. P. "Harriet Beecher Stowe." Eminent Women of the Age. Ed. James Parton. Hartford: S. M. Betts, 1868: 296-331.

Parton, James. Daughters of Genius: A Series of Sketches of Authors, Artists, Reformers, and Heroines, Queens, Princesses, and Women of Society, Women Eccentric and Peculiar. From the Most Recent and Authentic Sources. Philadelphia: Hubbard, 1888.

-. "International Copyright." Atlantic Monthly, October 1867, 430-51.

Patterson, Lyman Ray. Copyright in Historical Perspective. Nashville: Vanderbilt University Press, 1968.

Patterson, Lyman Ray, and Stanley W. Lindberg. The Nature of Copyright: A Law of Users' Rights. Athens: University of Georgia Press, 1991.

[Reventlow, Otto]. "Ist Uebersetzung Nachdruck?" New-Yorker Staats-Zeitung, April 6 1853, 2.

[Reventlow, Otto, and August Becker]. “'Onkel Tom's Hütte' in Deutschamerika.” Atlantische Studien, 1853, no. 2: 203-14.

Rice, Grantland S. The Transformation of Authorship in America. Chicago: Chicago University Press, 1997.

Robbins, Sarah. "Gendering the History of the Antislavery Narrative: Juxtaposing Uncle Tom's Cabin and Benito Cereno, Beloved and Middle Passage. American Quarterly 49 (1997): 531-73.

Rose, Mark. Authors and Owners: The Invention of Copyright. Cambridge: Harvard University Press, 1993.

"Mothers and Authors: Johnson v. Calvert and the New Children of Our Imagination." Critical Inquiry 22 (1996): 613-33.

Schäfer \& Koradi. “Oheim Toms Hütte” (advertisement). Philadelphier Demokrat, March 2, 1853, 3.

Schreyer, Alice D. "Copyright and Books in Nineteenth-Century America." Getting the Books Out: Papers of the Chicago Conference on the Book in $19^{\text {th }}$-Century America. Ed. Michael Hackenberg. Washington, D.C.: Center for the Book, Library of Congress, 1987: 121-36.

Smith, George Winston. Henry C. Carey and American Sectional Conflict. Albuquerque: University of New Mexico Press, 1951.

Smith, Susan Belasco. "Serialization and the Nature of Uncle Tom's Cabin." Periodical Literature in Nineteenth-Century America. Ed. Susan Belasco Smith and Kenneth M. Price. Charlottesville: University Press of Virginia, 1995: 69-89.

Smith, Sydney. Review of Statistical Annals of the United States of America, by Adam Seybert. Edinburgh Review 33 (January-May 1820): 69-80.

Spillers, Hortense. "Changing the Letter: The Yokes, the Jokes of Discourse, or, Mrs. Stowe, Mr. Reed." Uncle Tom's Cabin. Norton Critical Edition. Ed. Elizabeth Ammons. New York: Norton, 1994: 542-68.

Stanley, Amy Dru. "Conjugal Bonds and Wage Labor: Rights of Contract in the Age of Emancipation." Journal of American History 75 (1988): 471-50.

Stepto, Robert B. "Sharing the Thunder: The Literary Exchanges of Harriet Beecher Stowe, Henry Bibb, and Frederick Douglass." New Essays on Uncle Tom's Cabin. Ed. Eric Sundquist. New York: Cambridge University Press, 1986: 135-53. 
Story, Joseph. Commentaries on Equity Jurisprudence. Boston: Hilliard, Gray, 1836.

Stowe, Charles Edward. Life of Harriet Beecher Stowe compiled from her Letters and Journals, by her Son Charles Edward Stowe. Boston: Houghton, Mifflin, 1889.

Stowe, Harriet Beecher. Caban F'ewthr Twm. Remsen, N.Y.: J. R. Everett, 1854. . "Copyright and Natural Right: Letter from Harriet Beecher Stowe." NewYork Daily Tribune, September 16, 1852, 4.

- Dred; Eine Erzählung aus den Grossen Dismal-Sumpfe. Boston: Phillips, Sampson, 1856.

Oheim Tom's Hütte: oder, Das Leben bei den Niedrigen. Trans. Hugo Rudolph Hutten. Boston: J. P. Jewett, 1853.

- "Onkel Tom's Hütte, oder Das Leben unter den Niedrigen. Von Harriet Beecher Stowe. Uebersetzung der Redaktion. (Forstetzung.) Kapitel VIII." Beobachter am Ohio, February 14, 1853.

. "Onkel Tom's Hütte, oder; Leben unter den Verstossenen. Nach dem Englischen der Mrs. Harriet Beecher Stowe." Trans. Adolf Strodtmann. Die Freie Presse (Philadelphia), January 1-March 29, 1853.

- Onkel Tom's Hütte, oder: Leben unter den Verstossnen. Nach dem Englischen der Mrs. Harriet Beecher Stowe, frei bearbeitet von Adolf Strodtmann. Trans. Adolf Strodtmann. Philadelphia: Verlag von F. W. Thomas, 1853. . Uncle Tom's Cabin. Boston: Houghton, Osgood, 1879.

- Uncle Tom's Cabin, or Life Among the Lowly. New York: Penguin, 1981.

Stowe v. Thomas. 23 Fed. Cas. 201; 2 Wall. Jr. 547; Am. Law Reg. 210.

Stowe $v$. Thomas. Manuscript folder 9-10/1852. National Archives Mid-Atlantic Regional Branch, Philadelphia.

Sundquist, Eric, ed. New Essays on Uncle Tom's Cabin. New York: Cambridge University Press, 1986.

Swartz, Richard G. "Patrimony and the Figuration of Authorship in the Eighteenth-Century Literary Property Debates." Works and Days 7 (1989): 29-54.

Swisher, Carl B. History of the Supreme Court of the United States. Vol. 5: The Taney Period 1836-64. New York: Macmillan, 1974.

Tompkins, Jane P. Sensational Designs: The Cultural Work of American Fiction 1790-1860. New York: Oxford University Press, 1985.

Twain, Mark. Christian Science, with Notes Containing Corrections to Date. New York: Harper and Brothers, 1907.

"Uncle Tom Abroad." National Era, March 24, 1853.

"'Uncle Tom' at Law." New-York Weekly Tribune, April 16, 1853, 3-4.

"Uncle Tom in Court." Sunday Dispatch (Philadelphia), December 25, 1853, [3].

"Uncle Tom's Cabin." North American and United States Gazette (Philadelphia), December 26, 1853, 1.

United States. Congress Joint Committee on the Library. Report. 42nd. Cong., 3rd. sess. S. Rept. 409. Washington: Government Printing Office, 1873.

Webster, Noah. A Dictionary of the English Language: Abridged from the American Dictionary, for Use of Primary Schools and the Counting House. New York: F. J. Huntington, 1839.

Weis \& Wick. "Oheim Toms Hütte" (advertisement). Philadelphier Demokrat, March 2, 1853, 3.

Weisert, John J. "Lewis N. Dembitz and Onkel Tom's Hütte." German American Review 19 (February 1953): 7-8.

[When Mrs. Stowe was composing Uncle Tom's Cabin]. Woman's Journal 1, no. 1 (January 15, 1870): 16.

Wilson, Forrest. Crusader in Crinoline: The Life of Harriet Beecher Stowe. Philadelphia: Lippincott, 1941.

Wittke, Carl. The German-Language Press in America. Lexington, Ky.: University of Kentucky Press, 1957. 
Woodmansee, Martha. "The Genius and the Copyright: Economic and Legal Conditions for the Emergence of the "Author." Eighteenth-Century Studies 17 (1984): 425-48.

Woodmansee, Martha, and Peter Jaszi, eds. The Construction of Authorship: Textual Appropriation in Law and Literature. Durham: Duke University Press, 1994.

Zucker, A. E. "Biographical Dictionary of the Forty-Eighters." The Forty-Eighters: Political Refugees of the German Revolution of 1848. New York: Columbia University Press, 1950: 268-357. 